\title{
GENDER DIVERSITY IN LEADERSHIP AND FIRM PERFORMANCE: EVIDENCE FROM THE CZECH REPUBLIC
}

\author{
Veronika HEDIJA (1D 1*, Daniel NĚMEC(102 \\ ${ }^{1}$ Department of Economic Studies, College of Polytechnics Jihlava, Jihlava, Czech Republic \\ ${ }^{2}$ Department of Economics, Masaryk University, Faculty of Economics and Administration, \\ Brno, Czech Republic
}

Received 03 September 2019; accepted 20 August 2020

\begin{abstract}
The paper examines the effect of gender composition of executive body on financial performance and financial health of the firms. The data of more than thousand Czech travel agencies and tour operators for the period 2008-2015 was employed in the paper. To test the relationship between firm performance and gender diversity in leadership, the regression model was applied. After using alternative measurement for gender diversity of executive body and controlling for firm size, firm age, executive body size, leverage ratio and industry, the results have shown that the gender composition of executive body has no statistically significant effect on both firm performance and financial health of firms. The study deepens empirical knowledge about the relationship between gender diversity of executive body and corporate performance and financial health and brings new insights into the link between these phenomena in the Czech Republic.
\end{abstract}

Keywords: gender, women in leadership, gender diversity, financial performance, financial health, bankruptcy models.

JEL Classification: J16, J7, G3, M5.

\section{Introduction}

Gender diversity and its impact on corporate performance have been currently heavily discussed and actual topics. Women have been underrepresented at every level of corporate governance in a global context. In the USA, women occupied 20.2 percent of total board seats and 19.7 percent of senior level positions in the Fortune 500 companies in 2016 (Deloitte, 2017). In Europe, women held 24 percent of corporate seats and 15 percent of executives in the largest European firms in 2016 (Eurostat, 2018).

To increase the chance of women to get into governing bodies, the gender diversity within these bodies is supported by various means. In the European Union, the efforts on the issue of gender diversity in corporate boardrooms have emerged since the mid-1990s, in the form

${ }^{\star}$ Corresponding author. E-mail: veronika.hedija@vspj.cz 
of 96/694/EC Council Recommendation on the balanced participation of women and men in decision-making process recommends the member states to adopt integrated strategies to promote the representation of women and men in decision-making positions and to support initiatives to promote gender equality. Since 2010, gender equality has been promoted through Gender Equality Strategies. However, progress in this area has been only slow. This resulted in the preparation of the proposal for a Directive on promoting equality in decision making (Proposal for a Directive of the European Parliament and of the Council on Improving the Gender Balance among Non-Executive Directors of Companies Listed on Stock Exchanges and Related Measures from November 2012 (European Commission, 2012)). This proposal included a mandatory 40 percent quota for the representation of under-represented sex for non-executive board members of listed companies (Deloitte, 2017a). However, this proposal has not been adopted yet when some member states prefer their own way of regulating this area. Hence, the gender equality provisions have remained different in individual European Union member states. Several European Union countries have launched legally binding quotas for women on corporate boards (France: 40 percent; Austria: 35 percent; Belgium, Italy, Greece: 33 percent and Germany: 30 percent) other have introduced mandatory corporate governance rules or recommendations to provide equal opportunities (Desvaux et al., 2017). These measures and the emphasis on reducing inequalities between men and women in managing positions are certainly correct from an ethical point of view. Nevertheless, the economic effect of these measures stays a puzzle.

A lot of empirical papers have already probed into the relationship between the proportion of women in leadership and corporate performance. However, the results are not uniform. While some studies found a positive link between female representation and corporate performance (e.g. Khan \& Vieito, 2013; Lückerath-Rovers, 2013; Carter et al., 2003), the others revealed no (Miller \& del Carmen Triana, 2009; Rose, 2007) or a negative relationship (e.g. Ahern \& Dittmar, 2012; He \& Huang, 2011; Adams \& Ferreira, 2009). Hence, the evidence of the effect of gender diversity on corporate executive bodies on corporate performance remains inconclusive. The representation of women at different management levels and on corporate boards differs significantly across all countries (Devillard et al., 2012). The differences in the proportion of women in leadership as well as the effect of female leading on corporate performance could be driven by a variety of country-specific socio-economic factors and could be also industry-specific. This paper helps to solve this puzzle within the economic framework of Czech Republic.

Studies focusing on the influence of women in management on the financial performance of companies most often use indicators of profitability in terms of return on assets, return on sales, return on equity or Tobin Q as indicator of financial performance (Joecks et al., 2013). However, the profitability of the company does not provide a complete image of the company's long-term perspective and its overall financial health. From this point of view, it is appropriate to supplement the indicators of profitability with other indicators that measure debt, liquidity or activity. Existing literature draws attention to the different management styles of men and women, where the feminine leadership style also called as social-expressive pay attention on social aspects and relationship-oriented and the masculine leadership style is primarily task-based oriented (e.g. Audet et al., 2003; Radu et al., 2017). Feminine 
management style may also be characterized by higher risk aversion (He et al., 2007). Thus, companies led by women may be characterized by higher liquidity and lower indebtedness and these indicators play an important role in assessing financial health. According to our knowledge, a study examining the relationship between gender diversity of executive bodies and the financial health of a company is missing and this study brings the new insights in this field.

The aim of the paper is to examine the effect of gender composition of executive body on financial performance and financial health of travel agencies and tour operators using Czech data for the period 2008-2015.

In the European context, the Czech Republic belongs to countries having a relatively low proportion of women in leadership. The statistical data shows that women's representation on corporate boards has reached 10 percent which is 14 percentage points under the European average in 2016 (Eurostat, 2018). According to critical mass theory the positive effect of gender diversity on firm performance starts to emerge after reaching a certain proportion of women in executive body (Kanter, 1977). The subsector of travel agencies and tour operators belongs to the sectors having relatively high representation of women in executive bodies. According to data from the Czech Business Register, women represented the 40 percent of executive body members in 2015. From this perspective the sector of travel agents seems to be appropriate to analyze the relationship between gender diversity in executive bodies and corporate performance, when the relatively high proportion of women make possible the identification of any positive effect. The Czech economy has not subjected to any sectorspecific regulations regarding gender diversity in corporate governance yet, the selection of only one industry did not seem problematic from this point of view. If the effect of gender diversity in leadership on corporate performance and financial health is positive, it may be a signal that the pressure on reaching higher proportion of women in leadership would contribute to an increase of financial performance and health of Czech companies. On the other hand, it is necessary to consider specifics of the examined industry which may be attractive and suitable for women with regard to their abilities and preferences.

This paper is structured as follows. The first section provides the evidence of the importance of gender composition of executive body on firm performance. The second section focuses on the description of data and the models employed in the paper. The last section describes the empirical results and discusses the findings.

\section{Gender diversity in leadership and firm performance}

Gender issues and issues of discrimination against women in the labour market received relatively much attention over the past decades. One of the ways in which this research was directed was also the issue of representation of women in leadership and its influence on various aspects of operation and behaviour of the company. A relatively great attention was paid to examining the effect of gender diversity of corporate boards and management on firm performance.

From the theoretical point of view, gender diversity in corporate executive body can influence performance through many channels. Economic literature offers a number of theories 
explaining the relationship between gender diversity in governing bodies and corporate performance. These theories include most frequently upper echelons theory, agency theory and resource dependency theory (Campbell \& Bohdanowicz, 2015).

Upper echelons theory states that the firm outcomes are determined by the characteristics of top management team members, including experiences, values and personalities (Hambrick \& Mason, 1984; Ellwood \& Garcia-Lacalle, 2015). Man and women can differ in their characteristics and thus board gender diversity can influence the firm performance. A higher proportion of women on boards can improve creativity and critical thinking (Christiansen et al., 2016; Lee \& Farh, 2004). Shrader et al. (1997) assume that managerial talent is distributed normally among women and men in the case of greater representation of women on boards and improves organizational learning and climate too. Greater gender diversity brings increased heterogeneity in attitudes, beliefs or values which could improve the decision making process. On the other hand, higher proportion of women in leadership could also result in factors which have a negative effect on corporate performance. For instance, the results by Melsom (2015) indicated a positive relationship between female managers and sickness absence rates, or Lee and Farh (2004) suggested the existence of lower group cohesion in gender mixed groups.

From the agency theory point of view, the higher proportion of women on boards could improve the financial performance due to better monitoring and supervising the activity of the firm (Campbell \& Bohdanowicz, 2015). Female members of boards are more active, ask questions more often compared to male members, are better prepared for meetings (Virtanen, 2012; Adams \& Ferreira, 2009). All these factors could contribute to improve the decision making process.

Finally, resource dependency theory emphasizes the influence of external factors on organizational behavior, in context of this theory, managers could act to reduce environmental uncertainty and dependence (Hillman et al., 2009). Pfeffer (1972) shows that boards enable firms to minimize dependence and receive resources. Women on board and gender diversity can improve the firm performance because of women bring different and valuable perspective to the boards. For example, Arfken et al. (2004) emphasize that women know the behavior of certain markets and consumers better than men.

The results of empirical studies examining the relationship between gender composition of boards/management and firm performance are mixed. Some studies confirmed the positive relationship between proportion of women in leadership and firm performance (e.g. Beltran, 2019; Flabbi et al., 2019; Lückerath-Rovers, 2013; Carter et al., 2003). On the other hand, there are also studies that identified no or negative effect of women in leadership on firm performance (e.g. Adams \& Ferreira, 2009; Miller \& del Carmen Triana, 2009; Ahern \& Dittmar, 2012; He \& Huang, 2011; Ellwood \& Garcia-Lacalle, 2015; Wang, 2020). A detailed overview is presented for example by Joecks et al. (2013) and Christiansen et al. (2016).

The ambiguous results and conclusions may arise from different sources: the studies used different business performance indicators, different gender diversity measures, and they differed also in the number of involved control variables and applied methods. Moreover, the relationship was studied using the data sets of different countries and within different time periods (Joecks et al., 2013). 
Kanter's critical mass theory and institutional theory can then be used to explain the differences between countries. According to Kanter's critical mass theory (Kanter, 1977), the effect of women representation on boards on corporate performance is mixed and determined by gender composition of the examined group. This theory postulates that until a certain "critical mass" of women in a group is reached, this group does not benefit from different abilities and skills that women bring into the group. Torchia et al. (2011) confirmed that the proportion of women could play an important role in forming the firm strategy and level of innovation. They concluded that the increase of number of women on corporate board from one or two to at least three women (consistent minority) was possible to increase the level of firm innovation. Hence, the positive effect of gender diversity may not be fully realized in the countries or industries with low gender diversity on boards. Grosvold and Brammer (2010) or Cook and Glass (2014) examined the impact of institutional environment on representation of women on corporate boards. They showed that the national institutional system and mainly culturally and legally-oriented institutions play an important role in shaping board diversity.

The studies testing the link between women representation on boards/management and firm performance used mostly U.S. data or data from Nordic countries (e.g. Khan \& Vieito, 2013; Ahern \& Dittmar, 2012; He \& Huang, 2011; Miller \& del Carmen Triana, 2009; Adams \& Ferreira, 2009; Rose, 2007; Carter et al., 2003). However, corporate behaviour, corporate culture and gender stereotypes are country-specific to some extent which could affect the conclusions. Recently there have been also studies exploring this phenomenon in other European countries such as Germany (Joecks et al., 2013), the United Kingdom (Haslam et al., 2010; Pasaribu, 2017), the Netherlands (Lückerath-Rovers, 2013), Italy (Gallucci et al., 2015) or Spain (Campbell \& Mínguez-Vera, 2008) or using the data of selected European companies (Green \& Homroy, 2018; Christiansen et al., 2016). There are only a few studies devoted to post-communist countries.

To our knowledge, there are only two papers dealing with this issue using Czech data, i.e. Janošová and Mikuš (2018) and Černík (2016). Both mentioned studies did not find a significant effect of gender diversity in corporate executive body on corporate performance. Janošová and Mikuš (2018) tested the link between gender diversity and corporate performance using the data of selected firms from IT industry. They applied correlation coefficient regardless of other important factors of corporate performance. Černík (2016) used the regression model and 2SLS estimator. Nevertheless, he did not take non-linearity of the examined relationship into account and he used only a small sample of heterogeneous Czech firms. Moreover, both studies tested the relationship between gender diversity of executive body of firms and its economic performance measured by indicators of profitability. This study aims to deepen the existing knowledge (1) it takes into account the possible non-linearity of tested relationship, (2) examines the effect of gender diversity not only on profitability but also on financial performance measured by bankruptcy models and (3) following the Kanter's critical mass theory it uses the data of selected industry having the relative high proportion of women in executive body.

From this perspective, this study brings new insights into the problem of gender diversity and it tries to fill the existing gap in the empirical literature. 


\section{Data and methods}

The data for assessing the financial performance and health of the firms were obtained from the Albertina CZ Gold Edition database. This database contains information on all profit and non-profit entities in the Czech Republic that have been assigned a personal identification number (IČ). At present, this database covers the data of more than 2.7 million subjects. The data for travel agencies and tour operators (group 79.1 Travel agency and tour operator activities; 79.11 Travel agency activities; 79.12 Tour operator activities) was selected for the period 2008-2015 using Statistical classification of economic activities in the European Community Rev.2 (NACE Rev.2). The data for gender composition of executive body of the firms for the period 2008-2015 was obtained from the Business Register.

Firstly, the sample was narrowed down and only entities whose data contained all the information necessary for assessing financial health and financial performance were selected. Than we chose the firms which were active in the examined period and their sales were higher than 4,230 US dollars (approximately 100,000 CZK) per year in all examined years. The final sample comprised data of more than thousand firms with data of most of the firms were not available for the entire time period. The number of firms in each year is shown in Table 2 . According to Eurostat (2018) data, it represents on average 11 percent of travel agencies and tour operators in the Czech Republic in each year. In terms of firm size, small and mediumsized businesses predominate in the Czech travel agents market. According to the European Commission definition for small and medium-sized enterprises, small and medium-sized companies represent the vast majority of the companies included in the sample and small companies form more than 90 percent of sample. ${ }^{1}$

The aim of the paper is to examine the relationship between gender composition of executive body, financial performance and financial health. More existing methods could be applied to assess financial performance and overall health of a company. Most of them are based on selected financial ratios or on a combination of these (Hult et al., 2008).

To assess financial performance, two of the most frequently used indicators of profitability and financial performance were employed: return on assets (ROA) and return on sales (ROS) (Hult et al., 2008). Return on assets (ROA) was computed as earnings before interest and taxes (EBIT) divided by total assets; and return on sales (ROS) is earnings before interest and taxes (EBIT) divided by sales. Return on equity (ROE) belongs also to the group of frequently used indicators of firm performance. Nevertheless, ROA and ROS enable to capture the performance of firms independently of the proportion of equity and debt used by the company. For this reason, they were used in the analysis.

The selected bankruptcy models were used for examining financial health. Bankruptcy models belong to the frequently used models that enable to distinguish the firms having good financial health and businesses that are in financial distress and are threatened by bankruptcy. Specifically, Altman's Z'-Score model and model IN05 were employed (Altman,

\footnotetext{
${ }^{1}$ Commission Recommendation 2003/361/EC of 6 May 2003 defines micro, small and medium-sized enterprises. The small and medium-sized company employ fewer than 250 employees and have an annual turnover not exceeding 50 million EUR, and/or an annual balance sheet total not exceeding 43 million EUR. Small companies employ fewer than 50 employees and have an annual turnover and/or an annual balance sheet total not exceeding 10 million EUR.
} 
1983; Neumaierová \& Neumaier, 2005). According to previous studies testing the reliability of the selected bankruptcy models, these models have become suitable bankruptcy models for the Czech Republic (Altman et al., 2017; Machek, 2013).

Altman Z'-Score model could by described as follow (Altman, 1983):

$$
Z^{\prime}=0.717 A_{1}+0.847 A_{2}+3.107 A_{3}+0.420 A_{4}+0.998 A_{5},
$$

where $A_{1}$ is working capital/total assets, $A_{2}$ denotes retained earnings/total assets, $A_{3}$ is EBIT/ total assets, $A_{4}$ represents book value of equity/book value of total liabilities, $A_{5}$ is sales/total assets, and $Z^{\prime}$ is overall index.

According to value of $Z^{\prime}$-Score, financially distressed and non-distressed entities could be identified. If $Z^{\prime}$ is smaller than 1.23 , the firm is threatened by bankruptcy (Distress zone); if $Z^{\prime}$ is higher than 2.90 , the firm is in a good financial condition without any financial distress (Safe zone) and the values between 1.23 and 2.90 denotes Grey zone, where the conclusion is not clear.

Index IN05 is a country-specific bankruptcy model for the Czech Republic which was created and published by Neumaierová and Neumaier (2005). This model is an analogy of Altman's Z-Score model derived for Czech conditions. It has been estimated using discriminatory analysis on the data of Czech firms and showed good predicative ability with probability of the accuracy of the estimates exceeding 90 percent in the case of distress and safe zone (Neumaierová \& Neumaier, 2005). This model is an analogy of Altman's Z-Score model derived for Czech conditions and it could be described as follows (Neumaierová \& Neumaier, 2005):

$$
I N 05=0.13 N_{1}+0.04 N_{2}+3.97 N_{3}+0.21 N_{4}+0.09 N_{5},
$$

where $N_{1}$ is total assets/total liabilities, $N_{2}$ represents EBIT/interest expenses, $N_{3}$ is EBIT/ total assets, $N_{4}$ is total revenues/total assets and $N_{5}$ represents current assets/short-term liabilities. EBIT is computed as profit/loss before tax and interest expenses. IN05 is the value of the index. According to the authors of the model recommendation, maximum value 9 for component $\mathrm{N}_{2}$ was used to avoid overvaluation of the index in the case of very low or zero interest expenses. The firms could be divided into three zones by index values: IN05 $\leq 0.9$ is Distress zone; $0.9<$ IN05 $\leq 1.6$ is Grey zone and, IN05 > 1.6 denotes Safe zone.

According to Kanter's critical mass theory the relationship between firm performance and gender diversity of boards is not linear. Positive effect of gender diversity on firm performance starts to emerge after reaching a certain proportion of women in executive body (Kanter, 1977). Kanter (1977) defined four categories that behave differently depending on the share of the minority in the group: uniform groups (only men or women), skewed groups (up to 20 percent of minority), tilted groups (20-40 percent of minority) and balanced group (40-60 percent of women). This objection was considered when searching for suitable measurement for gender composition of executive body. Following this theory and as well as Kanter (1977) in her original work, the categories according to proportion of women in executive body were used: (1) men led firms (only men in executive body), (2) skewed executive body (0.1-20 percent of women in executive body), (3) tilted executive body (20.1-40 percent of women in executive body), (4) balanced executive body (40.1-60 percent of women in executive body), (5) tilted executive body 2 (60.1-80 percent of women in executive body), 
(6) skewed executive body 2 (80.1-99.9 percent of women in executive body), (7) women led firms (only women in executive body). The number of firms (and percentage share of firms) in each group is shown in Table 1. The situation in the examined period for full sample of firms is presented in fourth row of Table 1. The firms under study are mostly medium or small firms having only few members in their executive bodies in many cases and the executive body of 60 percent of firms consists of only one member (Table 1). These firms having only one executive (man or woman) belong to the uniform groups and this group will predominate in the sample. To take into account this fact, the sample is split into two groups: firms having only one member of executive body and firms having two or more members of executive body. Subsequently, the number of firms in each group is presented separately in second and third row of the Table 1.

Table 1. Number of firms according to the proportion of women in executive body in 2008-2015

\begin{tabular}{|c|c|c|c|c|c|c|c|c|}
\hline $\begin{array}{l}\text { Proportion of } \\
\text { women in exe- } \\
\text { cutive body }\end{array}$ & $\begin{array}{c}0 \\
\text { per- } \\
\text { cent of } \\
\text { women }\end{array}$ & $\begin{array}{l}0.1-20 \\
\text { per- } \\
\text { cent of } \\
\text { women }\end{array}$ & $\begin{array}{c}20.1-40 \\
\text { per- } \\
\text { cent of } \\
\text { women }\end{array}$ & $\begin{array}{l}40.1-60 \\
\text { per- } \\
\text { cent of } \\
\text { women }\end{array}$ & $\begin{array}{l}60.1-80 \\
\text { per- } \\
\text { cent of } \\
\text { women }\end{array}$ & $\begin{array}{c}80.1- \\
99.9 \\
\text { per- } \\
\text { cent of } \\
\text { women }\end{array}$ & $\begin{array}{l}100 \text { per- } \\
\text { cent of } \\
\text { women }\end{array}$ & Total \\
\hline $\begin{array}{l}\text { Firms having } \\
\text { only one } \\
\text { member of } \\
\text { executive body }\end{array}$ & $\begin{array}{l}1,356 \\
(56 \%) \\
(73 \%)\end{array}$ & - & - & - & - & - & $\begin{array}{l}1,065 \\
(44 \%) \\
(85 \%)\end{array}$ & $\begin{array}{c}2,421 \\
(100 \%) \\
(60 \%)\end{array}$ \\
\hline $\begin{array}{l}\text { Firms having } \\
\text { two or more } \\
\text { members of } \\
\text { executive body }\end{array}$ & $\begin{array}{c}504 \\
(32 \%) \\
(27 \%)\end{array}$ & $\begin{array}{c}3 \\
(0 \%) \\
(100 \%)\end{array}$ & $\begin{array}{c}137 \\
(9 \%) \\
(100 \%)\end{array}$ & $\begin{array}{c}699 \\
(44 \%) \\
(100 \%)\end{array}$ & $\begin{array}{c}56 \\
(4 \%) \\
(100 \%)\end{array}$ & $\begin{array}{c}0 \\
(0 \%) \\
(100 \%)\end{array}$ & $\begin{array}{c}187 \\
(12 \%) \\
(15 \%)\end{array}$ & $\begin{array}{l}1,586 \\
(100 \%) \\
(40 \%))\end{array}$ \\
\hline All firms & $\begin{array}{c}1,860 \\
(46 \%) \\
(100 \%)\end{array}$ & $\begin{array}{c}3 \\
(0 \%) \\
(100 \%)\end{array}$ & $\begin{array}{c}137 \\
(3 \%) \\
(100 \%)\end{array}$ & $\begin{array}{c}699 \\
(17 \%) \\
(100 \%)\end{array}$ & $\begin{array}{c}56 \\
(1 \%) \\
(100 \%)\end{array}$ & $\begin{array}{c}0 \\
(0 \%) \\
(100 \%)\end{array}$ & $\begin{array}{c}1,252 \\
(31 \%) \\
(100 \%)\end{array}$ & $\begin{array}{c}4,007 \\
(100 \%) \\
(100 \%)\end{array}$ \\
\hline
\end{tabular}

The data shown in Table 1 are very interesting. If we focus on full sample (all firms), the distribution of firms into each group is not balanced. The large number of examined firms have a uniform executive body where the executive body consists only of men (46 percent of firms) or women (31 percent of firms). 17 percent of firms have balanced executive body (40-60 percent of women). On the other hand, only very small number of the firms fit the description of skewed groups. This is consistent with critical mass theory that postulates that these groups show lower performance than uniform, tilted and balanced groups. This composition of executive bodies then occurs rarely due to natural tendency to apply more powerful models. The firms having only one member of executive body represent 60 percent of firms. The management of these companies is relatively equally divided between men and women, with 56 percent of these companies being controlled by men and the remaining 44 percent by women. Firms having two or more members of executive body represent 40 percent of surveyed firms. The firms having balanced executive bodies form 44 percent of this subsample. The equally large group is also consisted of companies having uniform executive body ( 32 percent of firms have only men in executive body and 12 percent of firms only 
women in executive body), however, firms led by men predominate here. This may be due, on the one hand, to the fact that it is more difficult for women to assert themselves in management positions, and, on the other hand, to the fact that women in leadership find it easier to accept male members either as a balancing element or to increase status of executive body.

As an alternative measure of gender diversity, Blau index was applied. It belongs to the very frequently used indicators of diversity in gender studies (Campbell \& Mínguez-Vera, 2008; He \& Huang, 2011; Joecks et al., 2013). Blau's index is calculated as $1-\sum_{i=1}^{2} P_{i}^{2}$, where $i$ stands for sex (male, female), $P_{i}$ is the percentage of executive body members in each category. The values of the Blau's index for board gender diversity range from 0 to 0.5 , where the value of 0.5 means the equal number of men and women in an executive body (Blau, 1977).

To quantify the relationship between financial health, financial performance and gender composition of executive body, regression model was used.

$$
\begin{aligned}
Y_{i t}= & \beta_{1} \cdot \text { gender compexecutive bod }_{i t-1}+\beta_{2} \cdot \ln \text { firm size }_{i t}+\beta_{3} \cdot \text { firmage }_{i t}+ \\
& \beta_{4} \cdot \text { leverage }_{i t}+\beta_{5} \cdot \text { executive body size }_{i t}+\beta_{6} \cdot N A C E_{i}+\beta_{7 t} \cdot T_{t}+u_{t},
\end{aligned}
$$

where $i$ denotes firm, $t$ is year, $Y_{i t}$ is economic performance or financial health of the $i$-th firm in year $t$, gender comp executive body $y_{i t-1}$ denotes gender composition of executive body of the $i$-th firm in year $t-1$, firm size $e_{i t}$ is the size of the $i$-th firm in year $t$, firm age $e_{i}$ is the age of $i$-th firm in year $t$, leverage ${ }_{i t}$ is the leverage of $i$-th firm in year $t$, executive body size $e_{i t}$ denotes the number of person in executive body of $i$-th firm in year $t, N A C E_{i}$ is the dummy variable for industry of $i$-th firm and $u_{i t}$ is the disturbance term. $\beta_{6} \cdot N A C E_{i}$ is the vector of industry-specific fixed effects and $\beta_{7 t} . T_{t}$ is a vector of time-specific fixed effects.

As the dependent variable, an estimate of financial performance (measured by ROA and ROS) or financial health (measured by $Z^{\prime}$-Score and IN05) was employed. As the explanatory variable of the gender composition of executive body, two alternative indicators were used: (1) a categorical variable consisting of seven categories according to proportion of women in executive body, (2) Blau index of gender diversity. To solve the problem of endogeneity of proportion of women in executive body, lagged values of explanatory variables were used. Joecks et al. (2013) have shown that the relationship between gender diversity and corporate performance is not linear but rather $\mathrm{U}$-shaped. To take also this objection about the potential non-linearity of the examined relationship into consideration, also quadratic form of the Blau index was used.

To achieve the robustness of the results, it was controlled for the firm size, the firm age, the executive body size, the leverage and the industry. The mentioned variables are traditionally used in a large number of studies focused on corporate performance and gender diversity (Joecks et al., 2013; Adams \& Ferreira, 2009; Campbell \& Mínguez-Vera, 2008). It was not controlled for independence of the executive body when this variable belongs to usual board characteristics and is frequently used in corporate board analyses (Adams \& Ferreira, 2009; Green \& Homroy, 2018). There are several reason for non-inclusion of this variable into regression. Firstly, the lack of the data as well as the fact that in the case of small firms which predominated in the sample the sample can be expected only low executive body independence. 
The firm size is measured by the sum of total assets. The firm size could be one of the factor affecting firm performance. Nevertheless, the relationship between firm performance and a firm size is not clear. From the economic theory point of view, the large firms could realize the economies of scale and scope and reach lower costs due to specialization and more effective implementation of operations. They could also benefit from higher competitive power. Contrary, smaller firms could be more flexible and respond quickly to market changes and achieve better financial performance compared to larger firms (Majumdar, 1997).

The firm age is measured as the number of years since the founding of the company. From the theoretical point of view, also the age of firm could affect the firm performance but even here the link is not clear. The older firm could benefit from experience, reputation and built business relationships and networks. These factors might be the reason for higher economic performance of older firms. On the other hand, the younger ones could be more flexible, they could suffer less bureaucracy and they are more active in seeking of market opportunities. (Majumdar, 1997; Agiomirgianakis et al., 2006; Kuncová et al., 2016).

The executive body size is measured by the number of members of the executive body of firm. It belongs also to the factors that could affect firm performance and as well as in the previous cases, the link is not clear here. The large board size allows representation of various shareholders and stakeholders and enables greater specialization and expertise of individual members. It could strengthen the firm performance by better monitoring and controlling the activities of managers by a large group of people. On the other hand, more conflicts can arise in large executive bodies, individual members cannot express their opinion properly. The board membership become just an honest function and the board members have only symbolic role. These factors speak for the negative impact of a large executive body on firm performance (Kalsie \& Shrivastav, 2016).

The leverage is calculated as the ratio of total debt to total assets. It reflects the financing of the company and the riskiness of the business in financial terms. High leverage ratio can cause financial problems and affect firm performance also in operation activities. The use of foreign capital allows the company to develop their activity more quickly and strengthening the firm performance. On the other hand, it can signal problems in the management of the company and create low confidence in the company (Ibhaguia \& Olokoyob, 2018).

The industry is measured by dummies according to NACE classification Rev. 2. Two categories are distinguished, travel agency activities and tour operator activities. In contrast to the operation of travel agencies, the activities of tour operators are subject to a certain degree of regulation in the Czech Republic. It is also more difficult to enter this sector. These factors may affect the performance of firms in each subsector.

The Ordinary Least Squares estimator (OLS) with robust standard errors and firm fixed effects in all models was applied. According to the results of the Hausman test, the random effects estimator (RE) was used in selected cases where the time-invariant variables emerged.

The descriptive statistics are shown in Table 2. The table shows that the most variables did not change very dramatically in the individual years. Significant changes could be noticed in the development of $Z^{\prime}$-Score and IN05 index, where these indexes significantly declined in 2009. This decline can be explained by the financial crisis of 2008 , which was fully reflected in the Czech economy just in these years. The decrease of demand, profitability and liquidity 
resulted in a deterioration in the average financial health of companies. Significant changes can be also seen in the case of company size, when the average size of companies (measured by the amount of total assets in thousands of US dollars) decreased. This can be explained by the reaction of firms to the economic downturn and the effort to optimize its size and financial structure.

Table 2. Descriptive statistics

\begin{tabular}{|c|c|c|c|c|c|c|c|c|}
\hline & 2008 & 2009 & 2010 & 2011 & 2012 & 2013 & 2014 & 2015 \\
\hline$Z^{\prime}$-Score & $\begin{array}{c}4.9459 \\
(5.4190)\end{array}$ & $\begin{array}{c}4.2634 \\
(4.7824)\end{array}$ & $\begin{array}{c}4.4295 \\
(5.1819)\end{array}$ & $\begin{array}{c}4.6527 \\
(6.7182) \\
\end{array}$ & $\begin{array}{l}4.2856 \\
(5.989)\end{array}$ & $\begin{array}{c}4.6117 \\
(9.6077)\end{array}$ & $\begin{array}{c}4.4620 \\
(7.4644)\end{array}$ & $\begin{array}{c}4.3722 \\
(6.5218) \\
\end{array}$ \\
\hline IN05 & $\begin{array}{c}1.6518 \\
(4.2373) \\
\end{array}$ & $\begin{array}{c}1.0275 \\
(9.4312)\end{array}$ & $\begin{array}{c}1.5668 \\
(6.6291) \\
\end{array}$ & $\begin{array}{c}1.7869 \\
(4.9237)\end{array}$ & $\begin{array}{c}1.8375 \\
(4.5408) \\
\end{array}$ & $\begin{array}{l}1.8472 \\
(6.688)\end{array}$ & $\begin{array}{c}2.4227 \\
(11.857) \\
\end{array}$ & $\begin{array}{c}1.9032 \\
(4.8476) \\
\end{array}$ \\
\hline ROA & $\begin{array}{c}0.0410 \\
(0.3077) \\
\end{array}$ & $\begin{array}{l}-0.0114 \\
(0.3331) \\
\end{array}$ & $\begin{array}{c}0.0069 \\
(0.3597) \\
\end{array}$ & $\begin{array}{c}0.0105 \\
(0.3338) \\
\end{array}$ & $\begin{array}{c}0.0155 \\
(0.3082) \\
\end{array}$ & $\begin{array}{l}-0.0054 \\
(0.3589) \\
\end{array}$ & $\begin{array}{l}0.0280 \\
(0.271) \\
\end{array}$ & $\begin{array}{c}0.0347 \\
(0.2592) \\
\end{array}$ \\
\hline ROS & $\begin{array}{c}0.0078 \\
(0.2177)\end{array}$ & $\begin{array}{l}-0.0066 \\
(0.3182)\end{array}$ & $\begin{array}{l}-0.0098 \\
(0.2508)\end{array}$ & $\begin{array}{l}-0.0193 \\
(0.2751)\end{array}$ & $\begin{array}{l}-0.0327 \\
(0.3994)\end{array}$ & $\begin{array}{l}-0.0190 \\
(0.3349)\end{array}$ & $\begin{array}{l}-0.0053 \\
(0.3426)\end{array}$ & $\begin{array}{c}0.0101 \\
(0.1962)\end{array}$ \\
\hline $\begin{array}{l}\text { Proportion } \\
\text { of women in } \\
\text { executive body }\end{array}$ & $\begin{array}{c}0.4196 \\
(0.4419)\end{array}$ & $\begin{array}{c}0.4083 \\
(0.4366)\end{array}$ & $\begin{array}{c}0.4082 \\
(0.4344)\end{array}$ & $\begin{array}{c}0.4120 \\
(0.4373)\end{array}$ & $\begin{array}{c}0.4398 \\
(0.4355)\end{array}$ & $\begin{array}{c}0.4308 \\
(0.4354)\end{array}$ & $\begin{array}{c}0.4166 \\
(0.4326)\end{array}$ & $\begin{array}{c}0.4263 \\
(0.4305)\end{array}$ \\
\hline Blau index & $\begin{array}{c}0.0973 \\
(0.1948)\end{array}$ & $\begin{array}{c}0.1028 \\
(0.1992)\end{array}$ & $\begin{array}{c}0.1064 \\
(0.2020)\end{array}$ & $\begin{array}{c}0.1028 \\
(0.2000)\end{array}$ & $\begin{array}{c}0.1143 \\
(0.2074)\end{array}$ & $\begin{array}{c}0.1120 \\
(0.2049)\end{array}$ & $\begin{array}{c}0.1125 \\
(0.2057)\end{array}$ & $\begin{array}{c}0.1191 \\
(0.2091)\end{array}$ \\
\hline Firm size ${ }^{1)}$ & $\begin{array}{l}717.279 \\
(3507.0) \\
\end{array}$ & $\begin{array}{l}780.311 \\
(3981.0)\end{array}$ & $\begin{array}{l}736.547 \\
(4023.4)\end{array}$ & $\begin{array}{l}760.996 \\
(4050.4)\end{array}$ & $\begin{array}{l}777.134 \\
(4219.1) \\
\end{array}$ & $\begin{array}{l}616.324 \\
(3318.3) \\
\end{array}$ & $\begin{array}{l}453.252 \\
(1736.3) \\
\end{array}$ & $\begin{array}{l}488.881 \\
(1749.6)\end{array}$ \\
\hline Firm age & $\begin{array}{c}9.1265 \\
(4.9134) \\
\end{array}$ & $\begin{array}{l}10.1526 \\
(4.9542)\end{array}$ & $\begin{array}{l}10.3888 \\
(5.3022)\end{array}$ & $\begin{array}{c}10.9418 \\
(5.545) \\
\end{array}$ & $\begin{array}{l}11.3665 \\
(5.8671) \\
\end{array}$ & $\begin{array}{c}11.129 \\
(6.2238)\end{array}$ & $\begin{array}{l}11.9505 \\
(6.3238) \\
\end{array}$ & $\begin{array}{l}12.4058 \\
(6.663)\end{array}$ \\
\hline Leverage & $\begin{array}{l}0.8456 \\
(0.732)\end{array}$ & $\begin{array}{c}0.8048 \\
(0.5958)\end{array}$ & $\begin{array}{c}0.8208 \\
(0.6634)\end{array}$ & $\begin{array}{c}0.8175 \\
(0.7254)\end{array}$ & $\begin{array}{c}0.7815 \\
(0.6301)\end{array}$ & $\begin{array}{c}0.8080 \\
(0.6884)\end{array}$ & $\begin{array}{c}0.7664 \\
(0.6634)\end{array}$ & $\begin{array}{c}0.7717 \\
(0.6637)\end{array}$ \\
\hline $\begin{array}{l}\text { Executive body } \\
\text { size }\end{array}$ & $\begin{array}{c}1.5058 \\
(0.7234)\end{array}$ & $\begin{array}{c}1.5188 \\
(0.7135)\end{array}$ & $\begin{array}{c}1.5135 \\
(0.7132)\end{array}$ & $\begin{array}{c}1.4678 \\
(0.6673)\end{array}$ & $\begin{array}{c}1.5077 \\
(0.7275)\end{array}$ & $\begin{array}{c}1.5194 \\
(0.7974)\end{array}$ & $\begin{array}{c}1.4841 \\
(0.7132)\end{array}$ & $\begin{array}{c}1.5096 \\
(0.7239)\end{array}$ \\
\hline \multicolumn{9}{|l|}{$\begin{array}{l}\text { Executive body } \\
\text { members }\end{array}$} \\
\hline $\begin{array}{l}\text { Only one } \\
\text { member }\end{array}$ & 0.6031 & 0.5892 & 0.5946 & 0.6154 & 0.5982 & 0.6095 & 0.6131 & 0.6058 \\
\hline $\begin{array}{l}\text { Two or more } \\
\text { members }\end{array}$ & 0.3969 & 0.4108 & 0.4054 & 0.3846 & 0.4018 & 0.3905 & 0.3869 & 0.3942 \\
\hline \multicolumn{9}{|l|}{$\mathrm{NACE}^{2)}$} \\
\hline 79.10 & 0.0661 & 0.0610 & 0.0541 & 0.0728 & 0.0949 & 0.1113 & 0.1201 & 0.1212 \\
\hline 79.11 & 0.4475 & 0.4296 & 0.4407 & 0.4532 & 0.4592 & 0.4611 & 0.4753 & 0.5019 \\
\hline 79.12 & 0.4864 & 0.5094 & 0.5052 & 0.4740 & 0.4459 & 0.4276 & 0.4046 & 0.3769 \\
\hline $\mathrm{N}$ & 514 & 426 & 481 & 481 & 453 & 566 & 566 & 520 \\
\hline
\end{tabular}

Note: 1) Total assets in thousands of US dollars, 2) share in individual groups (mean of dummy variables), standard errors in parentheses. 


\section{Results and discussion}

Firstly, the relationship between representation of women in executive body and firm financial performance/financial health was examined using very simple method. The firms were divided into groups according to the proportion of women in executive body and then compared the economic performance/health of firms in each group. The data for the year 2015 was used. The results are shown in Table 3 and Table 4.

Table 3 presents the results of bankruptcy models used for assessment of financial health of examined firms in 2015. The results are very similar for both applied bankruptcy models. We can see that approximately 50 percent of all examined firms are in a good financial condition and 25 percent of examined firms are in a financial distress. After dividing firms according to the proportion of women in executive body, it can be concluded that results are very similar for both the men led firms ( 0 percent of women in executive body) and the women led firms (100 percent of women in executive body). In both groups, approximately a quarter of firms suffer from financial distress and a half of firms are in safe zone. The financial health of firms having balanced executive body (40-60 percent of women in executive body) is only slightly better comparing to women and men led firms. The situation is very different in both groups of tilted executive body firms (20-40 percent of women in executive body and 60-80 percent of women in executive body). While the financial health of companies with 20-40 percent of women in executive body is below average, the financial health of companies with 60-80 percent of women in executive body is, on the contrary, significantly above the average. However, these findings need to be treated with caution due to small number of these companies.

Table 3. Financial health of travel agencies and tour operators in 2015 according to the proportion of women in executive body (number of firms)

\begin{tabular}{|c|c|c|c|c|c|c|c|c|c|}
\hline & \multicolumn{3}{|c|}{ All firms } & \multicolumn{3}{|c|}{0 percent of women } & \multicolumn{3}{|c|}{ 20.1-40 percent of women } \\
\hline & $\begin{array}{l}\text { Distress } \\
\text { zone }\end{array}$ & $\begin{array}{l}\text { Grey } \\
\text { zone }\end{array}$ & $\begin{array}{l}\text { Safe } \\
\text { zone }\end{array}$ & $\begin{array}{l}\text { Distress } \\
\text { zone }\end{array}$ & $\begin{array}{l}\text { Grey } \\
\text { zone }\end{array}$ & $\begin{array}{l}\text { Safe } \\
\text { zone }\end{array}$ & $\begin{array}{l}\text { Distress } \\
\text { zone }\end{array}$ & $\begin{array}{l}\text { Grey } \\
\text { zone }\end{array}$ & $\begin{array}{l}\text { Safe } \\
\text { zone }\end{array}$ \\
\hline$Z^{\prime}$-Score & $\begin{array}{c}122 \\
(23 \%)\end{array}$ & $\begin{array}{c}126 \\
(24 \%)\end{array}$ & $\begin{array}{c}272 \\
(52 \%)\end{array}$ & $\begin{array}{c}50 \\
(22 \%)\end{array}$ & $\begin{array}{c}58 \\
(25 \%)\end{array}$ & $\begin{array}{c}123 \\
(53 \%)\end{array}$ & $\begin{array}{c}12 \\
(46 \%)\end{array}$ & $\begin{array}{c}3 \\
(12 \%)\end{array}$ & $\begin{array}{c}11 \\
(42 \%)\end{array}$ \\
\hline IN05 & $\begin{array}{c}137 \\
(26 \%)\end{array}$ & $\begin{array}{c}133 \\
(26 \%)\end{array}$ & $\begin{array}{c}250 \\
(48 \%)\end{array}$ & $\begin{array}{c}59 \\
(26 \%)\end{array}$ & $\begin{array}{c}61 \\
(26 \%)\end{array}$ & $\begin{array}{c}111 \\
(48 \%)\end{array}$ & $\begin{array}{c}9 \\
(35 \%)\end{array}$ & $\begin{array}{c}8 \\
(31 \%)\end{array}$ & $\begin{array}{c}9 \\
(35 \%)\end{array}$ \\
\hline \multirow[t]{3}{*}{$\mathrm{N}$} & \multicolumn{3}{|c|}{520} & \multicolumn{3}{|c|}{231} & \multicolumn{3}{|c|}{26} \\
\hline & \multicolumn{3}{|c|}{$40.1-60$ percent of women } & \multicolumn{3}{|c|}{$60.1-80$ percent of women } & \multicolumn{3}{|c|}{100 percent of women } \\
\hline & $\begin{array}{l}\text { Distress } \\
\text { zone }\end{array}$ & $\begin{array}{l}\text { Grey } \\
\text { zone }\end{array}$ & $\begin{array}{l}\text { Safe } \\
\text { zone }\end{array}$ & $\begin{array}{l}\text { Distress } \\
\text { zone }\end{array}$ & $\begin{array}{l}\text { Grey } \\
\text { zone }\end{array}$ & $\begin{array}{l}\text { Safe } \\
\text { zone }\end{array}$ & $\begin{array}{l}\text { Distress } \\
\text { zone }\end{array}$ & $\begin{array}{l}\text { Grey } \\
\text { zone }\end{array}$ & $\begin{array}{l}\text { Safe } \\
\text { zone }\end{array}$ \\
\hline$Z^{\prime}$-Score & $\begin{array}{c}19 \\
(20 \%)\end{array}$ & $\begin{array}{c}24 \\
(25 \%) \\
\end{array}$ & $\begin{array}{c}52 \\
(55 \%) \\
\end{array}$ & $\begin{array}{c}0 \\
(0 \%) \\
\end{array}$ & $\begin{array}{c}1 \\
(14 \%)\end{array}$ & $\begin{array}{c}6 \\
(86 \%) \\
\end{array}$ & $\begin{array}{c}41 \\
(25 \%) \\
\end{array}$ & $\begin{array}{c}40 \\
(25 \%) \\
\end{array}$ & $\begin{array}{c}80 \\
(50 \%) \\
\end{array}$ \\
\hline IN05 & $\begin{array}{c}24 \\
(25 \%)\end{array}$ & $\begin{array}{c}21 \\
(22 \%)\end{array}$ & $\begin{array}{c}50 \\
(53 \%)\end{array}$ & $\begin{array}{c}0 \\
(0 \%)\end{array}$ & $\begin{array}{c}2 \\
(29 \%)\end{array}$ & $\begin{array}{c}5 \\
(71 \%)\end{array}$ & $\begin{array}{c}45 \\
(28 \%)\end{array}$ & $\begin{array}{c}41 \\
(25 \%)\end{array}$ & $\begin{array}{c}75 \\
(47 \%)\end{array}$ \\
\hline $\mathrm{N}$ & \multicolumn{3}{|c|}{95} & \multicolumn{3}{|c|}{7} & \multicolumn{3}{|c|}{161} \\
\hline
\end{tabular}

Note: Distress zone: $\mathrm{Z}^{\prime} \leq 1.23$, IN05 $\leq$ 0.9; Grey zone: $1.23<\mathrm{Z}^{\prime} \leq 2.9,0.9<\mathrm{IN} 05 \leq 1.6$; Safe zone: $\mathrm{Z}^{\prime}>2.9$, IN05 > 1.6. 
The financial performance measured by return on assets and return on sales depending on gender composition of executive body is shown in Table 4 . The results are very similar for individual profitability ratios. The data shows that the financial performance of firms having balanced executive body is not better than performance of uniform executive body firms but is more or less similar. The conclusions for both groups of tilted executive body firms vary significantly where the financial performance of firm having 20-40 percent of women in executive body is below average and performance of firm having 60-80 percent representation of women in executive body is significantly above average. Finally, the financial performance of women led firms is higher than men led firms using both profitability ratios.

Table 4. Financial performance of travel agencies and tour operators in 2015 (mean of profitability ratios)

\begin{tabular}{|c|c|c|c|c|c|c|}
\hline All firms & $\begin{array}{c}\text { 0 percent of } \\
\text { women }\end{array}$ & $\begin{array}{c}20.1-40 \\
\text { percent of } \\
\text { women }\end{array}$ & $\begin{array}{c}40.1-60 \\
\text { percent of } \\
\text { women }\end{array}$ & $\begin{array}{c}60.1-80 \\
\text { percent of } \\
\text { women }\end{array}$ & $\begin{array}{c}\text { 100 percent } \\
\text { of women }\end{array}$ \\
\hline ROA & 0.0347 & 0.0258 & 0.0110 & 0.0363 & 0.0729 & 0.0488 \\
& $(0.2592)$ & $(0.2638)$ & $(0.1640)$ & $(0.2393)$ & $(0.0549)$ & $(0.2820)$ \\
\hline ROS & 0.0101 & 0.0084 & -0.0737 & 0.0195 & 0.0338 & 0.0193 \\
& $(0.1962)$ & $(0.1911)$ & $(0.4592)$ & $(0.1300)$ & $(0.0412)$ & $(0.1677)$ \\
\hline N & 520 & 231 & 26 & 95 & 7 & 161 \\
\hline
\end{tabular}

However, these results may be somewhat misleading. There are many factors that can have a significant impact on a financial performance and a financial health of a firm. Empirical studies have shown that the size of the firm or its age belong to the leading factors of firm performance (e.g. Majumdar, 1997; Coad et al., 2013). Industry (subsector), size of executive body and other factors may also play an important role. The uneven distribution of these factors among surveyed groups of companies can lead to distorted conclusions.

To take the above-mentioned objections into account, the data for the period 2008-2015 was used and a regression model was applied to estimate the impact of gender diversity of executive body on business performance and financial health. The conclusions are shown in Tables 5 to 11 . As the dependent variable, an estimate of financial performance (measured by ROA and ROS) or financial health (measured by Z'-Score and IN05) were used. As explanatory variables, lagged value of composition of executive body was applied. For most robustness of the results, two alternative indicators of executive body composition were used containing a categorical variable consisting of seven categories of executive body gender composition and Blau index of gender diversity. Finally, it was controlled for the firm size, the firm age, the executive body size, the leverage and the industry to take into account the impact of these factors.

Tables 5, 6 and 7 show the results of OLS and RE estimation with ROA, ROS, Z'-Score and IN05 as dependent variable and proportion of women in executive body in the form of dummy variables for different types of executive body as key explanatory variable and controlling for further variables (Eq. (3)). Firstly, the regression models were estimated for full sample of firms (Table 5). However, most of the companies in the sample are represented by 
small firms which are managed by only one person (man or woman). The management of these companies has its specifics and can differ from the management of larger companies, where the final decision is the result of a consensus of more members. In addition, these companies are always led only by a man or a woman and they do not allow us to assess the impact of mixed executive body on firm performance and financial health. Controlling for executive body size in the regression model partly solve this problem. However, for most robust results the firms were split into two subsamples according to executive body size: (1) firms having only one executive and (2) firms having two or more executives. Then regression models were estimated separately for each subsample (Table 6 and 7).

Using the full sample of firms, the results have shown that the proportion of women in executive body is not a significant factor affecting neither firm performance (measured by ROE and ROS) nor financial health (measured by $Z^{\prime}$-Score and IN05) (Table 5). The regression coefficients for all groups representing the proportion of women on boards are not statistically significant. The only exceptions are selected groups in the model (3) and model (4). In the case of model (3) the regression coefficient for skewed executive body 1 (0-20 percent of women) is statistically significant and suggests the better value of ROS of firms having this compositions of executive body as compared with men led firms. However, using the ROA as the indicator of firm performance (model 1) does not confirm the impact of this type of management on business performance. In addition, a very small number of firms had this composition of board, so the results are not important. Using model (4) the regression coefficients for tilted executive body 2 (60-80 percent of women) and women led firms (100 percent of women) are statistically significant and indicate that firms having these gender compositions of executive body have lower value of $Z^{\prime}$-Score (and lower financial health) in comparison with men led firms (0 percent of women in executive body). However, the results have not been confirmed with using IN05 as an indicator of financial health.

Concerning the link between other explanatory variables and firm financial performance and financial health, firm size and leverage are the significant factors affecting firm performance and financial health.

The positive relationship between firm size and financial performance (ROA, ROS) and a negative relationship between firm size and financial health ( $Z^{\prime}$-Score, IN05) have been found out. According to economic theory, the relationship between firm size and firm performance is ambiguous. Larger firms could profit from the economies of scale and the formalization of procedures and operations. On the other hand, these firms can suffer from worse corporate governance. However, higher performance of larger companies in our case is not so surprising and this conclusion is consistent with the findings of large number of empirical studies (Majumdar, 1997; Agiomirgianakis et al., 2006; Guest, 2009; Joecks et al., 2013; Kuncová et al., 2016) where the positive effects of firm size predominated. On the other hand, Konečný and Ćástek (2016) came to the opposite conclusion using the data of Czech firms. The link between the firm size and its financial performance can therefore be sector-specific. Paradoxically lower financial health of larger firms compared to smaller ones can be explained by their stronger bargaining position that allows them to have lower liquidity and higher financial obligations in comparison with smaller firms. 
The negative effect of leverage on financial performance (ROA and ROS) and also on financial health ( $Z$ '-Score and IN05) has been identified. The firms having higher level of leverage achieve lower financial performance and lower financial health. These conclusions are in line with the part of empirical studies (e.g. Phillips \& Sipahioglu, 2004; Ibhaguia \& Olokoyob, 2018) that as well found the negative effect of leverage on financial performance of firms.

Table 5. OLS- and RE-regression models estimation for proportion of women in executive body - all firms

\begin{tabular}{|c|c|c|c|c|c|}
\hline Variables & $\begin{array}{c}\text { ROA } \\
\text { (OLS) } \\
(1)\end{array}$ & $\begin{array}{c}\text { ROS } \\
\text { (OLS) } \\
(2)\end{array}$ & $\begin{array}{l}\text { ROS } \\
\text { (RE) } \\
(3)\end{array}$ & $\begin{array}{c}Z^{\prime} \text {-Score } \\
\text { (OLS) } \\
(4)\end{array}$ & $\begin{array}{c}\text { IN05 } \\
\text { (OLS) } \\
\text { (5) }\end{array}$ \\
\hline \multicolumn{6}{|c|}{$\begin{array}{l}\text { Proportion of women } \\
\text { in executive body }(t-1)\end{array}$} \\
\hline $0.1-20$ percent & $\begin{array}{c}0.0898 \\
(0.1343)\end{array}$ & $\begin{array}{c}0.1153 \\
(0.1273)\end{array}$ & $\begin{array}{l}0.0918^{\star *} \\
(0.0385)\end{array}$ & $\begin{array}{l}-2.7352 \\
(4.2309)\end{array}$ & $\begin{array}{c}9.0696 \\
(8.7374)\end{array}$ \\
\hline 20.1-40 percent & $\begin{array}{l}-0.0333 \\
(0.0570)\end{array}$ & $\begin{array}{l}0.0025 \\
(0.0479)\end{array}$ & $\begin{array}{c}0.0287 \\
(0.0549)\end{array}$ & $\begin{array}{l}-6.4460 \\
(5.0310)\end{array}$ & $\begin{array}{l}-0.5445 \\
(1.7286)\end{array}$ \\
\hline $40.1-60$ percent & $\begin{array}{l}-0.0648 \\
(0.0428)\end{array}$ & $\begin{array}{l}-0.0301 \\
(0.0455)\end{array}$ & $\begin{array}{l}-0.0130 \\
(0.0234)\end{array}$ & $\begin{array}{l}-1.9058 \\
(1.3506)\end{array}$ & $\begin{array}{c}1.3546 \\
(1.3941)\end{array}$ \\
\hline $60.1-80$ percent & $\begin{array}{l}-0.0610 \\
(0.0664)\end{array}$ & $\begin{array}{c}0.0032 \\
(0.0493)\end{array}$ & $\begin{array}{c}0.0145 \\
(0.0227)\end{array}$ & $\begin{array}{l}-4.1288^{* *} \\
(1.6393)\end{array}$ & $\begin{array}{c}0.5926 \\
(1.6382)\end{array}$ \\
\hline 100 percent & $\begin{array}{c}0.0199 \\
(0.0467)\end{array}$ & $\begin{array}{l}0.0097 \\
(0.0660)\end{array}$ & $\begin{array}{c}0.0116 \\
(0.0170)\end{array}$ & $\begin{array}{l}-1.6849^{*} \\
(0.9929)\end{array}$ & $\begin{array}{c}1.3642 \\
(1.1449)\end{array}$ \\
\hline Ln Firm size & $\begin{array}{l}0.0897^{* * *} \\
(0.0200)\end{array}$ & $\begin{array}{l}0.0556^{* * *} \\
(0.0213)\end{array}$ & $\begin{array}{c}0.0069 \\
(0.0054)\end{array}$ & $\begin{array}{c}-3.6910^{\star * *} \\
(0.5493)\end{array}$ & $\begin{array}{l}-2.0393^{*} \\
(1.1034)\end{array}$ \\
\hline Firm age & $\begin{array}{l}-0.0538^{* * *} \\
(0.0168)\end{array}$ & $\begin{array}{l}-0.0175 \\
(0.0129)\end{array}$ & $\begin{array}{c}0.0009 \\
(0.0012)\end{array}$ & $\begin{array}{l}-0.5460 \\
(1.2410)\end{array}$ & $\begin{array}{c}0.2304 \\
(1.6197)\end{array}$ \\
\hline Leverage & $\begin{array}{l}-0.2642^{* * *} \\
(0.0417)\end{array}$ & $\begin{array}{l}-0.0999^{* * *} \\
(0.0306)\end{array}$ & $\begin{array}{l}-0.1186^{\star * *} \\
(0.0207)\end{array}$ & $\begin{array}{l}-2.4216^{* * *} \\
(0.7225)\end{array}$ & $\begin{array}{l}-2.8478^{* * *} \\
(0.9999)\end{array}$ \\
\hline Executive body size & $\begin{array}{l}-0.0354^{* *} \\
(0.0178)\end{array}$ & $\begin{array}{l}-0.0185 \\
(0.0238)\end{array}$ & $\begin{array}{l}-0.0186 \\
(0.0114)\end{array}$ & $\begin{array}{c}0.1811 \\
(0.5355)\end{array}$ & $\begin{array}{l}-1.5307 \\
(1.1223)\end{array}$ \\
\hline NACE & Yes & Yes & Yes & Yes & Yes \\
\hline Firm fixed effects & Yes & Yes & - & Yes & Yes \\
\hline Constant & $\begin{array}{l}0.5475^{\star} \\
(0.2910)\end{array}$ & $\begin{array}{c}0.1634 \\
(0.1626)\end{array}$ & $\begin{array}{c}0.0692 \\
(0.0449)\end{array}$ & $\begin{array}{c}34.2761 \\
(23.2789)\end{array}$ & $\begin{array}{c}15.4959 \\
(26.5885)\end{array}$ \\
\hline $\mathrm{R}^{2}$ & 0.5363 & 0.5240 & - & 0.6693 & 0.3387 \\
\hline $\mathrm{N}$ & 3,493 & 3,493 & 3,493 & 3,493 & 3,493 \\
\hline
\end{tabular}

Note: Robust standard errors in parentheses, ${ }^{* * *} \mathrm{p}<0.01,{ }^{* *} \mathrm{p}<0.05,{ }^{\star} \mathrm{p}<0.1$.

The conclusions that the proportion of women in executive body does not have a statistically significant effect on the financial performance and health of firms were also confirmed using the sample of companies that have two or more members of executive body. The estimates of coefficients of regression models are presented in Table 6. Using the five percent level of significance, the regression coefficients for proportion of women in executive body 
are not statistically significant. The only exception is women led firms in model (2). Here, the results suggest the worse value of ROS of firms having this compositions of executive body as compared with men led firms. However, using the random effects estimator (model 3) and also the ROA as the alternative indicator of firm performance (model 1), the statistically significant impact of this type of management on firm performance has not confirmed at 0.05 level of significance.

Table 6. OLS- and RE-regression models estimation for proportion of women in executive body - firms having two or more members of executive body

\begin{tabular}{|c|c|c|c|c|c|c|}
\hline Variables & $\begin{array}{c}\text { ROA } \\
\text { (OLS) } \\
(1)\end{array}$ & $\begin{array}{l}\text { ROS } \\
\text { (OLS) } \\
\text { (2) }\end{array}$ & $\begin{array}{l}\text { ROS } \\
\text { (RE) } \\
(3)\end{array}$ & $\begin{array}{c}Z^{\prime} \text {-Score } \\
\text { (OLS) } \\
(4)\end{array}$ & $\begin{array}{c}\text { IN05 } \\
\text { (OLS) } \\
(5)\end{array}$ & $\begin{array}{c}\text { IN05 } \\
\text { (RE) } \\
(6)\end{array}$ \\
\hline \multicolumn{7}{|c|}{$\begin{array}{l}\text { Proportion of women } \\
\text { in executive body }(\mathrm{t}-1)\end{array}$} \\
\hline $0.1-20$ percent & $\begin{array}{c}0.0347 \\
(0.1315)\end{array}$ & $\begin{array}{l}-0.0031 \\
(0.1619)\end{array}$ & $\begin{array}{l}0.0990^{\star} \\
(0.0515)\end{array}$ & $\begin{array}{l}-8.5065 \\
(8.9030) \\
\end{array}$ & $\begin{array}{c}13.1429 \\
(11.3083)\end{array}$ & $\begin{array}{c}2.6678 \\
(1.5761)\end{array}$ \\
\hline 20.1-40 percent & $\begin{array}{l}-0.1163 \\
(0.0830)\end{array}$ & $\begin{array}{l}-0.1048 \\
(0.0801)\end{array}$ & $\begin{array}{c}0.0095 \\
(0.0585)\end{array}$ & $\begin{array}{c}-12.0196 \\
(8.7841)\end{array}$ & $\begin{array}{l}-0.3304 \\
(3.1272)\end{array}$ & $\begin{array}{c}1.3219 \\
(1.0582)\end{array}$ \\
\hline $40.1-60$ percent & $\begin{array}{l}-0.1868^{\star} \\
(0.0966)\end{array}$ & $\begin{array}{l}-0.2027^{\star} \\
(0.1061)\end{array}$ & $\begin{array}{l}-0.0514 \\
(0.0337)\end{array}$ & $\begin{array}{c}-7.384468 \\
(4.8285)\end{array}$ & $\begin{array}{c}1.8669 \\
(3.9447)\end{array}$ & $\begin{array}{c}0.4585 \\
(0.4697)\end{array}$ \\
\hline $60.1-80$ percent & $\begin{array}{l}-0.2091^{\star} \\
(0.1221)\end{array}$ & $\begin{array}{l}-0.2231^{\star} \\
(0.1164)\end{array}$ & $\begin{array}{l}-0.0255 \\
(0.0280)\end{array}$ & $\begin{array}{l}-9.2655^{*} \\
(4.8156)\end{array}$ & $\begin{array}{c}0.1725 \\
(4.2059)\end{array}$ & $\begin{array}{l}1.0037 \\
(0.9577)\end{array}$ \\
\hline 100 percent & $\begin{array}{l}-0.2758^{\star} \\
(0.1580)\end{array}$ & $\begin{array}{l}-0.3132^{\star *} \\
(0.1526)\end{array}$ & $\begin{array}{l}-0.0682^{\star} \\
(0.0382)\end{array}$ & $\begin{array}{l}-6.7465 \\
(4.6961)\end{array}$ & $\begin{array}{l}-0.1369 \\
(3.8204)\end{array}$ & $\begin{array}{l}0.4815 \\
0.5405\end{array}$ \\
\hline Ln Firm size & $\begin{array}{c}0.0861^{\star * *} \\
(0.0275)\end{array}$ & $\begin{array}{c}0.0318 \\
(0.0201)\end{array}$ & $\begin{array}{c}0.0013 \\
(0.0094)\end{array}$ & $\begin{array}{l}-3.8218^{* * *} \\
(0.6047)\end{array}$ & $\begin{array}{l}-1.0069^{*} \\
(0.5600)\end{array}$ & $\begin{array}{c}-0.3392^{\star *} \\
(0.1630)\end{array}$ \\
\hline Firm age & $\begin{array}{l}-0.1250^{* * *} \\
(0.0396)\end{array}$ & $\begin{array}{l}-0.0770^{* *} \\
(0.0376)\end{array}$ & $\begin{array}{c}0.0017 \\
(0.0020)\end{array}$ & $\begin{array}{c}0.5013 \\
(1.1484)\end{array}$ & $\begin{array}{c}1.1877 \\
(1.1870)\end{array}$ & $\begin{array}{c}-(0.0387) \\
(0.0586)\end{array}$ \\
\hline Leverage & $\begin{array}{l}-0.3408^{* * *} \\
(0.0747)\end{array}$ & $\begin{array}{c}-0.1780^{* * *} \\
(0.0593)\end{array}$ & $\begin{array}{c}-0.1954^{* * *} \\
(0.0437)\end{array}$ & $\begin{array}{l}-1.4789 \\
(2.0850)\end{array}$ & $\begin{array}{l}-1.6047 \\
(1.2928)\end{array}$ & $\begin{array}{l}-1.8670^{* * *} \\
(0.5116)\end{array}$ \\
\hline Executive body size & $\begin{array}{l}-0.0401^{\star *} \\
(0.0194)\end{array}$ & $\begin{array}{l}-0.0380 \\
(0.0323)\end{array}$ & $\begin{array}{l}-0.0299 \\
(0.0202)\end{array}$ & $\begin{array}{c}0.2172 \\
(0.2980)\end{array}$ & $\begin{array}{l}-1.1656 \\
(1.0687)\end{array}$ & $\begin{array}{c}-0.7143 \\
(0.5438)\end{array}$ \\
\hline NACE & Yes & Yes & Yes & Yes & Yes & Yes \\
\hline Firm fixed effects & Yes & Yes & - & Yes & Yes & - \\
\hline Constant & $\begin{array}{c}1.7183^{* * *} \\
(0.5564)\end{array}$ & $\begin{array}{l}1.2252^{\star *} \\
(0.5379)\end{array}$ & $\begin{array}{c}0.1795 \\
(0.0648)\end{array}$ & $\begin{array}{c}23.8737 \\
(20.1718)\end{array}$ & $\begin{array}{c}-8.5709 \\
(18.3608)\end{array}$ & $\begin{array}{c}5.5850^{* * *} \\
(1.1025)\end{array}$ \\
\hline $\mathrm{R}^{2}$ & 0.5940 & 0.6259 & - & 0.6329 & 0.3422 & - \\
\hline $\mathrm{N}$ & 1,324 & 1,324 & 1,324 & 1,324 & 1,324 & 1,324 \\
\hline
\end{tabular}

Note: Robust standard errors in parentheses, ${ }^{\star * *} \mathrm{p}<0.01,{ }^{* *} \mathrm{p}<0.05,{ }^{\star} \mathrm{p}<0.1$.

The influence of women in executive body on the performance or financial health of the firms has not been confirmed even in the companies that have only one executive body member and are thus managed by only one person (man of woman). The situation is shown in Table 7. The regression models (Eq. (3)) are estimated for subsample of firms having only one member of executive body. The regression coefficients for the explanatory variable female 
executive (100 percent of women in executive body) are not statistically significant. Hence, the gender of the executives is not the factor that would affect the performance and financial health of the firms.

Table 7. OLS- and RE-regression models estimation for proportion of women in executive body - firms having only one member of executive body

\begin{tabular}{|c|c|c|c|c|c|c|}
\hline Variables & $\begin{array}{l}\text { ROA } \\
\text { (OLS) } \\
(1)\end{array}$ & $\begin{array}{l}\text { ROS } \\
\text { (OLS) } \\
(2)\end{array}$ & $\begin{array}{l}\text { ROS } \\
\text { (RE) } \\
(3)\end{array}$ & $\begin{array}{c}Z^{\prime} \text {-Score } \\
\text { (OLS) } \\
(4)\end{array}$ & $\begin{array}{c}\text { IN05 } \\
\text { (OLS) } \\
(5)\end{array}$ & $\begin{array}{c}\text { IN05 } \\
\text { (RE) } \\
(6)\end{array}$ \\
\hline \multicolumn{7}{|l|}{$\begin{array}{l}\text { Proportion of women } \\
\text { in executive body } \\
(\mathrm{t}-1)\end{array}$} \\
\hline $\begin{array}{l}100 \text { percent (female } \\
\text { executive) }\end{array}$ & $\begin{array}{c}0.0835 \\
(0.0650)\end{array}$ & $\begin{array}{c}0.0671 \\
(0.1166)\end{array}$ & $\begin{array}{l}0.0344^{*} \\
(0.0199)\end{array}$ & $\begin{array}{l}-0.5062 \\
(0.9321)\end{array}$ & $\begin{array}{c}1.8886 \\
(1.7076)\end{array}$ & $\begin{array}{c}0.1472 \\
(0.8920)\end{array}$ \\
\hline Ln Firm size & $\begin{array}{l}0.0812^{\star * *} \\
(0.0299)\end{array}$ & $\begin{array}{l}0.0432^{* *} \\
(0.0176)\end{array}$ & $\begin{array}{c}0.0090 \\
(0.0063)\end{array}$ & $\begin{array}{c}-3.1869^{* * *} \\
(0.3431)\end{array}$ & $\begin{array}{c}-1.0603^{* * *} \\
(0.2589)\end{array}$ & $\begin{array}{c}-0.9246^{* * *} \\
(0.1997)\end{array}$ \\
\hline Firm age & $\begin{array}{l}-0.0394^{*} \\
(0.0231)\end{array}$ & $\begin{array}{l}-0.0077 \\
(0.0131)\end{array}$ & $\begin{array}{c}0.0002 \\
(0.0014)\end{array}$ & $\begin{array}{l}-0.6934 \\
(1.2412)\end{array}$ & $\begin{array}{l}-0.1754 \\
(1.5754)\end{array}$ & $\begin{array}{l}0.1033^{* *} \\
(0.0449)\end{array}$ \\
\hline Leverage & $\begin{array}{c}-0.2676^{* * *} \\
(0.0514)\end{array}$ & $\begin{array}{c}-0.0872^{* * *} \\
(0.0314)\end{array}$ & $\begin{array}{c}-0.0819^{* * *} \\
(0.0198)\end{array}$ & $\begin{array}{c}-2.3071^{\star * *} \\
(0.5225)\end{array}$ & $\begin{array}{l}-2.2464^{* * *} \\
(0.4047)\end{array}$ & $\begin{array}{c}-2.3550^{* * *} \\
(0.3882)\end{array}$ \\
\hline NACE & Yes & Yes & Yes & Yes & Yes & Yes \\
\hline Firm fixed effects & Yes & Yes & - & Yes & Yes & - \\
\hline Constant & $\begin{array}{c}0.1062 \\
(0.4404)\end{array}$ & $\begin{array}{c}0.0180 \\
(0.2002)\end{array}$ & $\begin{array}{c}0.0120 \\
(0.0459)\end{array}$ & $\begin{array}{c}33.8045 \\
(23.7160)\end{array}$ & $\begin{array}{c}16.0740 \\
(27.0407)\end{array}$ & $\begin{array}{l}6.6078^{\star * *} \\
(1.2719)\end{array}$ \\
\hline R2 & 0.5571 & 0.5245 & - & 0.8190 & 0.8174 & - \\
\hline $\mathrm{N}$ & 2,049 & 2,049 & 2,049 & 2,049 & 2,049 & 2,049 \\
\hline
\end{tabular}

Note: Robust standard errors in parentheses, ${ }^{* *} \mathrm{p}<0.01,{ }^{* *} \mathrm{p}<0.05,{ }^{\star} \mathrm{p}<0.1$.

To receive more robust results and to consider the gender diversity per se and possible nonlinearity of relationship between gender diversity and firm financial performance/health, Blau index and its squared as the measurement of gender diversity were used in regression. Blau's index range from 0 to 0.5 , where the value of 1 means uniform executive body and value of 0.5 means the equal number of men and women in an executive body. As in the previous case, the regression models were estimated for the full sample of firms and subsequently also for companies that have two or more executives.

The results for all firms are shown in Tables 8 and 9. Table 8 presents the results of OLS and RE estimation with ROA and ROS as dependent variable and Blau index as explanatory variable representing gender diversity of boards. Also the further controls were added to the models to filter out their effect on dependent variable. Table 9 presents the results of OLS regression models for Z'-Score and IN05 as dependent variable. The findings are consistent with our previous results. The significant link between gender diversity of boards and company's performance or its financial health has not been identified. The size of company and the leverage are only statistically significant factors affecting firm financial performance and financial health in the Czech subsector of travel agents. 
The same conclusions have been confirmed in the case of using a sample of companies having two or more executive body members (Tables 10 and 11). Even in this case, gender diversity of executive body has not affect the financial performance or the financial health of companies.

Table 8. OLS- and RE-regression models estimation for Blau index: explanatory variable financial performance - all firms

\begin{tabular}{|l|c|c|c|c|c|c|}
\hline \multicolumn{1}{|c|}{ Variables } & $\begin{array}{c}\text { ROA } \\
(\mathrm{OLS}) \\
(1)\end{array}$ & $\begin{array}{c}\text { ROA } \\
(\mathrm{OLS}) \\
(2)\end{array}$ & $\begin{array}{c}\text { ROS } \\
(\mathrm{OLS}) \\
(3)\end{array}$ & $\begin{array}{c}\text { ROS } \\
(\mathrm{OLS}) \\
(4)\end{array}$ & $\begin{array}{c}\text { ROS } \\
(\mathrm{RE}) \\
(5)\end{array}$ & $\begin{array}{c}\text { ROS } \\
(\mathrm{RE}) \\
(6)\end{array}$ \\
\hline Blau index \\
\end{tabular}

Note: Robust standard errors in parentheses, ${ }^{* *} \mathrm{p}<0.01,{ }^{* *} \mathrm{p}<0.05,{ }^{\star} \mathrm{p}<0.1$.

Table 9. OLS-regression models estimation for Blau index: explanatory variable firm financial health all firms

\begin{tabular}{|c|c|c|c|c|}
\hline Variables & $\begin{array}{c}Z^{\prime} \text {-Score } \\
\text { (OLS) } \\
(1)\end{array}$ & $\begin{array}{c}Z^{\prime} \text {-Score } \\
\text { (OLS) } \\
(2)\end{array}$ & $\begin{array}{l}\text { IN05 } \\
\text { (OLS) } \\
(3)\end{array}$ & $\begin{array}{l}\text { IN05 } \\
\text { (OLS) } \\
(4)\end{array}$ \\
\hline Blau index $_{(t-1)}$ & $\begin{array}{l}-3.8038 \\
(3.0232)\end{array}$ & $\begin{array}{l}-64.3411 \\
(48.7984)\end{array}$ & $\begin{array}{c}1.1305 \\
(2.2640)\end{array}$ & $\begin{array}{l}-20.5231 \\
(18.8644)\end{array}$ \\
\hline Blau index ${ }_{(t-1)}^{2}$ & - & $\begin{array}{l}123.1682 \\
(93.9101)\end{array}$ & - & $\begin{array}{c}44.0561 \\
(37.8089)\end{array}$ \\
\hline Ln Firm size & $\begin{array}{c}-3.6793^{* * *} \\
(0.5484)\end{array}$ & $\begin{array}{c}-3.6943^{* * *} \\
(0.5500)\end{array}$ & $\begin{array}{c}-2.0402^{*} \\
(1.1029)\end{array}$ & $\begin{array}{l}-2.0456^{*} \\
(1.1031)\end{array}$ \\
\hline Firm age & $\begin{array}{l}-0.5488 \\
(1.2419)\end{array}$ & $\begin{array}{l}-0.5344 \\
(1.2406)\end{array}$ & $\begin{array}{c}0.2166 \\
(1.6186)\end{array}$ & $\begin{array}{c}0.2217 \\
(1.6185)\end{array}$ \\
\hline Leverage & $\begin{array}{c}-2.4178^{\star * *} \\
(0.7200)\end{array}$ & $\begin{array}{c}-2.4305^{* * *} \\
(0.7210)\end{array}$ & $\begin{array}{c}-2.8694^{* * *} \\
(0.9975)\end{array}$ & $\begin{array}{c}-2.8736^{\star * *} \\
(0.9961)\end{array}$ \\
\hline
\end{tabular}


End of Table 9

\begin{tabular}{|l|c|c|c|c|}
\hline \multicolumn{1}{|c|}{ Variables } & $\begin{array}{c}\text { Z'-Score } \\
(\text { OLS }) \\
(1)\end{array}$ & $\begin{array}{c}\text { Z'-Score } \\
(\text { OLS }) \\
(2)\end{array}$ & $\begin{array}{c}\text { IN05 } \\
(\text { OLS }) \\
(3)\end{array}$ & $\begin{array}{c}\text { IN05 } \\
\text { (OLS) } \\
(4)\end{array}$ \\
\hline $\begin{array}{l}\text { Executive body } \\
\text { size }\end{array}$ & 0.0210 & 0.1359 & -1.5789 & -1.5378 \\
$(0.4874)$ & $(0.5214)$ & $(1.1141)$ & $(1.1167)$ \\
\hline NACE & Yes & Yes & Yes & Yes \\
\hline Firm fixed effects & Yes & Yes & Yes & Yes \\
\hline Constant & 32.8546 & 32.5648 & 17.0677 & 16.9641 \\
\hline $\mathrm{R}^{2}$ & $(23.2738)$ & $(23.2472)$ & $(26.5249)$ & $(26.5201)$ \\
\hline $\mathrm{N}$ & 0.6661 & 0.6678 & 0.3377 & 0.3379 \\
\hline
\end{tabular}

Note: Robust standard errors in parentheses, ${ }^{\star * *} \mathrm{p}<0.01,{ }^{\star *} \mathrm{p}<0.05,{ }^{\star} \mathrm{p}<0.1$.

Table 10. OLS- and RE-regression models estimation for Blau index: explanatory variable financial performance - firms having two or more members of executive body

\begin{tabular}{|c|c|c|c|c|c|c|}
\hline Variables & $\begin{array}{c}\text { ROA } \\
\text { (OLS) } \\
(1)\end{array}$ & $\begin{array}{c}\text { ROA } \\
\text { (OLS) } \\
\text { (2) }\end{array}$ & $\begin{array}{c}\text { ROS } \\
\text { (OLS) } \\
\text { (3) }\end{array}$ & $\begin{array}{c}\text { ROS } \\
\text { (OLS) } \\
(4)\end{array}$ & $\begin{array}{c}\text { ROS } \\
\text { (RE) } \\
\text { (5) }\end{array}$ & $\begin{array}{c}\text { ROS } \\
\text { (RE) } \\
(6)\end{array}$ \\
\hline Blau index $(t-1)$ & $\begin{array}{l}-0.2209 \\
(0.1536)\end{array}$ & $\begin{array}{c}0.8884 \\
(1.2043)\end{array}$ & $\begin{array}{l}-0.2154 \\
(0.1673)\end{array}$ & $\begin{array}{c}0.9336 \\
(0.7708)\end{array}$ & $\begin{array}{l}-0.0500 \\
(0.0609)\end{array}$ & $\begin{array}{c}0.7833 \\
(0.7217)\end{array}$ \\
\hline Blau index $_{(t-1)}^{2}$ & - & $\begin{array}{l}-2.2861 \\
(2.5669)\end{array}$ & - & $\begin{array}{l}-2.3681 \\
(1.7052)\end{array}$ & - & $\begin{array}{c}-1.700059 \\
(1.4731)\end{array}$ \\
\hline Ln Firm size & $\begin{array}{c}0.0830^{* * *} \\
(0.0272)\end{array}$ & $\begin{array}{c}0.0842^{* * *} \\
(0.0274)\end{array}$ & $\begin{array}{c}0.0280 \\
(0.0197)\end{array}$ & $\begin{array}{c}0.0292 \\
(0.0199)\end{array}$ & $\begin{array}{c}0.0037 \\
(0.0094)\end{array}$ & $\begin{array}{c}0.0033 \\
(0.0093)\end{array}$ \\
\hline Firm age & $\begin{array}{c}-0.1001^{\star * *} \\
(0.0339)\end{array}$ & $\begin{array}{c}-0.1038^{\star * *} \\
(0.0352)\end{array}$ & $\begin{array}{l}-0.0470 \\
(0.0303)\end{array}$ & $\begin{array}{l}-0.0509 \\
(0.0314)\end{array}$ & $\begin{array}{c}0.0018 \\
(0.0020)\end{array}$ & $\begin{array}{c}0.0018 \\
(0.0020)\end{array}$ \\
\hline Leverage & $\begin{array}{c}-0.3465^{* * *} \\
(0.0741)\end{array}$ & $\begin{array}{c}-0.3452^{* * *} \\
(0.0742)\end{array}$ & $\begin{array}{c}-0.1843^{* * *} \\
(0.0586)\end{array}$ & $\begin{array}{c}-0.1829^{* * *} \\
(0.0587)\end{array}$ & $\begin{array}{c}-0.1940^{\star * *} \\
(0.0434)\end{array}$ & $\begin{array}{c}-0.1941^{\star * *} \\
(0.0434)\end{array}$ \\
\hline $\begin{array}{l}\text { Executive body } \\
\text { size }\end{array}$ & $\begin{array}{c}-0.0403^{* *} \\
(0.0186)\end{array}$ & $\begin{array}{c}-0.0430^{* *} \\
(0.0197)\end{array}$ & $\begin{array}{l}-0.0376 \\
(0.0317)\end{array}$ & $\begin{array}{l}-0.0404 \\
(0.0322)\end{array}$ & $\begin{array}{l}-0.0201 \\
(0.0178)\end{array}$ & $\begin{array}{l}-0.0291 \\
(0.0208)\end{array}$ \\
\hline NACE & Yes & Yes & Yes & Yes & Yes & Yes \\
\hline $\begin{array}{l}\text { Firm fixed } \\
\text { effects }\end{array}$ & Yes & Yes & Yes & Yes & - & - \\
\hline Constant & $\begin{array}{l}1.3136^{* * *} \\
(0.4580)\end{array}$ & $\begin{array}{l}1.3821^{\star * *} \\
(0.4861)\end{array}$ & $\begin{array}{l}0.7331^{\star} \\
(0.4129)\end{array}$ & $\begin{array}{l}0.8042^{\star} \\
(0.4363)\end{array}$ & $\begin{array}{l}0.1226^{\star *} \\
(0.0601)\end{array}$ & $\begin{array}{l}0.1462^{\star *} \\
(0.0675)\end{array}$ \\
\hline $\mathrm{R}^{2}$ & 0.5918 & 0.5925 & 0.6232 & 0.6238 & - & - \\
\hline $\mathrm{N}$ & 1,324 & 1,324 & 1,324 & 1,324 & 1,324 & 1,324 \\
\hline
\end{tabular}

Note: Robust standard errors in parentheses, ${ }^{* *} \mathrm{p}<0.01,{ }^{* *} \mathrm{p}<0.05,{ }^{\star} \mathrm{p}<0.1$.

Our results are consistent with the findings of previous studies examining the relationship between women in executive body and firm performance in the Czech Republic, i.e. Janošová and Mikuš (2018) and Černík (2016). According to Grosvold and Brammer (2010) or Cook and Glass (2014) the national institutional system and mainly culturally and legally-oriented 
Table 11. OLS-regression models estimation for Blau index: explanatory variable firm financial health firms having two or more members of executive body

\begin{tabular}{|c|c|c|c|c|c|c|}
\hline Variables & $\begin{array}{c}Z^{\prime} \text {-Score } \\
\text { (OLS) } \\
\text { (1) }\end{array}$ & $\begin{array}{c}Z^{\prime} \text {-Score } \\
\text { (OLS) } \\
\text { (2) }\end{array}$ & $\begin{array}{l}\text { IN05 } \\
\text { (OLS) } \\
(3)\end{array}$ & $\begin{array}{l}\text { IN05 } \\
\text { (OLS) } \\
(4)\end{array}$ & $\begin{array}{l}\text { IN05 } \\
\text { (RE) } \\
(5)\end{array}$ & $\begin{array}{l}\text { IN05 } \\
\text { (RE) } \\
(6)\end{array}$ \\
\hline Blau index $_{(t-1)}$ & $\begin{array}{l}-13.858 \\
(9.2472)\end{array}$ & $\begin{array}{l}-76.3034 \\
(59.4625)\end{array}$ & $\begin{array}{c}2.4753 \\
(5.8061)\end{array}$ & $\begin{array}{l}-15.1336 \\
(18.4215)\end{array}$ & $\begin{array}{l}0.9561 \\
0.8941\end{array}$ & $\begin{array}{c}9.5278 \\
(16.3109)\end{array}$ \\
\hline Blau index ${ }^{2}(\mathrm{t}-1)$ & - & $\begin{array}{c}128.6912 \\
(105.3452)\end{array}$ & - & $\begin{array}{c}36.2897 \\
(40.0147)\end{array}$ & - & $\begin{array}{c}-17.43753 \\
(32.1904)\end{array}$ \\
\hline Ln Firm size & $\begin{array}{c}-3.8158^{* * *} \\
(0.6018)\end{array}$ & $\begin{array}{c}-3.8804^{\star * *} \\
(0.6214)\end{array}$ & $\begin{array}{l}-0.9689^{*} \\
(0.5468)\end{array}$ & $\begin{array}{l}-0.9871^{*} \\
(0.5501)\end{array}$ & $\begin{array}{c}-0.3543^{* *} \\
(0.1686)\end{array}$ & $\begin{array}{c}-0.3544^{\star *} \\
(0.1687)\end{array}$ \\
\hline Firm age & $\begin{array}{c}0.8160 \\
(0.9957)\end{array}$ & $\begin{array}{l}1.026985 \\
(0.8680)\end{array}$ & $\begin{array}{c}1.0502 \\
(0.8765)\end{array}$ & $\begin{array}{c}1.1097 \\
(0.8973)\end{array}$ & $\begin{array}{l}-0.0365 \\
(0.0580)\end{array}$ & $\begin{array}{l}-0.0368 \\
(0.0580)\end{array}$ \\
\hline Leverage & $\begin{array}{l}-1.5009 \\
(2.0574)\end{array}$ & $\begin{array}{l}-1.5752 \\
(2.0676)\end{array}$ & $\begin{array}{l}-1.6710 \\
(1.2986)\end{array}$ & $\begin{array}{l}-1.6919 \\
(1.2937)\end{array}$ & $\begin{array}{c}-1.8640^{\star * *} \\
(0.5084)\end{array}$ & $\begin{array}{c}-1.8696^{* * *} \\
(0.5066)\end{array}$ \\
\hline $\begin{array}{l}\text { Executive body } \\
\text { size }\end{array}$ & $\begin{array}{c}0.0233 \\
(0.2211)\end{array}$ & $\begin{array}{c}0.1759 \\
(0.2496)\end{array}$ & $\begin{array}{l}-1.2648 \\
(1.0648)\end{array}$ & $\begin{array}{l}-1.2217 \\
(1.0545)\end{array}$ & $\begin{array}{l}-0.4897 \\
(0.4347)\end{array}$ & $\begin{array}{l}-0.6240 \\
(0.5422)\end{array}$ \\
\hline NACE & Yes & Yes & Yes & Yes & Yes & Yes \\
\hline $\begin{array}{l}\text { Firm fixed } \\
\text { effects }\end{array}$ & Yes & Yes & Yes & Yes & - & - \\
\hline Constant & $\begin{array}{c}19.5109 \\
(17.9131) \\
\end{array}$ & $\begin{array}{c}15.6509 \\
(15.2348) \\
\end{array}$ & $\begin{array}{c}-6.0271 \\
(13.0536) \\
\end{array}$ & $\begin{array}{c}-7.1155 \\
(13.4323) \\
\end{array}$ & $\begin{array}{c}5.2694^{* * *} \\
(1.016)\end{array}$ & $\begin{array}{c}5.5776^{* * *} \\
(1.1109)\end{array}$ \\
\hline $\mathrm{R}^{2}$ & 0.6241 & 0.6275 & 0.3394 & 0.3397 & - & - \\
\hline $\mathrm{N}$ & 1,324 & 1,324 & 1,324 & 1,324 & 1,324 & 1,324 \\
\hline
\end{tabular}

Note: Robust standard errors in parentheses, ${ }^{* * *} \mathrm{p}<0.01,{ }^{* *} \mathrm{p}<0.05,{ }^{\star} \mathrm{p}<0.1$.

institutions play an important role in board diversity. National institutions and gender stereotypes could play an important role in explaining the effect of executive body diversity on firm financial performance. According to Hofstede Insights (2019), the Czech Republic ranks among the countries with a masculine culture. Women are still in the role of mothers and family cares, and their place in society is seen through this lens. The representation of women in management is low and the male management style is perceived as victorious (Křrižková, 2003; Dytrt, 2013). In this environment, women in leadership may adopt a male management style and hence, the benefits of gender diversity may not fully reap. According to surveys by the Public Opinion Research Center (2016), there has been some development towards a higher level of perception of the role of men and women in society in recent years in the Czech Republic. Taking into account the influence of institutions and their development over time, the gradual implementation of the principles of gender equality in Czech culture and the related gradual changes in behavior patterns, it can be expected that the examined relationship may evolve over time, and in the future there may be a positive effect of a higher representation of women in management on firm performance. 


\section{Conclusions}

The introduction of mandatory quotas for the proportion of women on boards and promoting the higher representation of women in leadership has been frequently discussed topic. The main objective of this measure is to guarantee gender equality but it has strong overlaps towards the performance of firms and, therefore, the economic performance and competitiveness of the whole economy.

This article brings new insights into this area. It aimed to examine the link between gender composition of executive body and financial performance and financial health of travel agencies and tour operators using Czech data.

The proportion of women in leadership is relatively low in the Czech Republic. Women represent approximately 10 percent of corporate boards members (Eurostat, 2018). Testing the relationship between the proportion of women in management and business performance and the estimation of real impact of women in leadership on firm performance can be problematic in these conditions. According to critical mass theory, the positive effect of women in management starts to emerge after reaching a certain proportion of women in leadership. The subsector of travel agencies and tour operators is one of the industries having relatively high proportion of women in management. The proportion of women in executive bodies reaches approximately 40 percent here. Hence, the tourism industry appeared to be relatively suitable for testing the relationship between gender diversity in leadership and firm performance in the conditions of the Czech Republic.

To examine the relationship between gender composition of executive body and financial performance and health, the regression model was used and the endogeneity problem and Kanter's critical mass theory implications were considered. For the robustness of the conclusions, alternative indicators of company performance (ROA and ROS) and financial health ( $Z$ '-Score and IN05) were used. The results have shown that the gender composition of executive body is not significant factor affecting neither firm performance nor financial health in the industry reporting high representation of women in leadership. Women led firms, men led firms and gender balanced executive body firms report very similar financial health and financial performance.

The study has several theoretical and also practical contributions. He extends the existing empirical evidence and brings new insights into the relationship between gender diversity of executive body and firm performance. The study (1) brought specific conclusions valid for the sector having naturally high proportion of women in leadership, (2) examined the impact of women in leadership not only on corporate performance but also on financial health, (3) brought new findings for the Czech Republic, where this issue was not given much attention.

The findings have also interesting practical implications for corporate governance and also for government policy. The study has shown that even in sectors where the representation of women in leadership is naturally high, higher proportion of women in leadership (or having gender-balanced executive body) is not the guarantee of higher financial performance. On the other hand, it has not been proved that higher proportion of women in leadership would have a negative impact on firm performance and health. In the case of small firms managed by only one person, it has been also shown that the firm performance is not affected 
by gender of executive. Thus, it can be stated that there is no need to worry that a higher proportion of women in leadership negatively affect corporate performance. On the contrary, the higher proportion of women in leadership could help to meet social goals in the form of gender equality without the negative impact on firm performance.

The findings that are presented here have also some limitations. They are valid for an industry where women are represented naturally well. In male-dominated industries, the conclusions may be somewhat different. The performance of female led firms in these industries may be lower due to their different cognitive and non-cognitive skills in comparison to men or due to possible discrimination in the market (this may come from customers, employees or other companies). The country-specific factors may play their role as well. From this point of view, our conclusions should not be fully generalized to other European countries. Also the data for period 2005-2015 are used in the study which could limit the relevance of the results for today. However, the issue of representation of women in management and their behavior is not an area that would change and develop dramatically. Changes in the patterns of behavior and actions of both men and women in management and changes in winning strategies are a long-term process. From this point of view, the conclusions of the study should be still valid a relevant for today.

This study focused on financial performance and health. In the background, there is also non-financial performance that reflects consumer satisfaction, quality of products and employee satisfaction and it is a very important component of the company's overall performance. Consideration of this dimension will be the subject of further research.

\section{Funding}

This research was supported by the College of Polytechnics, Jihlava, the Czech Republic, under Grant [no. 1170/26/423] "Attributes of business performance management and determining factors" and by the Masaryk University, Faculty of Economics and Administration, Brno, the Czech Republic, under specific research project [no. MUNI/A/0880/2019].

\section{Disclosure statement}

No potential conflict of interest was reported by the authors.

\section{References}

Adams, R. B., \& Ferreira, D. (2009). Women in the boardroom and their impact on governance and performance. Journal of Financial Economics, 94(2), 291-309. https://doi.org/10.1016/j.jfineco.2008.10.007

Agiomirgianakis, G., Voulgaris, F., \& Papadogonas, T. (2006). Financial factors affecting profitability and employment growth, the case of Greek manufacturing. International Journal of Financial Services Management, 1(2/3), 235-245. https://doi.org/10.1504/IJFSM.2006.009628

Ahern, K. R., \& Dittmar, A. K. (2012). The changing of the boards, The impact on firm valuation of mandated female board representation. The Quarterly Journal of Economics, 127(1), 137-197. https://doi.org/10.2139/ssrn.1364470 
Altman, E. I. (1983). Corporate financial distress, a complete guide to predicting, avoiding, and dealing with bankruptcy. Wiley Interscience, John Wiley and Sons.

Altman, E. I., Iwanicz-Drozdowska, M., Laitinen, E. K., \& Suvas, A. (2017). Financial distress prediction in an international context, a review and empirical analysis of Altman's Z-Score model. Journal of International Financial Management \& Accounting, 28(2), 131-170. https://doi.org/10.1111/jifm.12053

Arfken, D. E., Bellar, S. L., \& Helms, M. M. (2004). The ultimate glass ceiling revisited: The presence of women on corporate boards. Journal of Business Ethics, 50(2), 177-186. https://doi.org/10.1023/B:BUSI.0000022125.95758.98

Audet, L., Miller, J. C., \& Appalbaum, S. H. (2003). Gender and leadership? Leadership and gender? A journey through the landscape of theories. Leadership \& Organization Development Journal, 24(1), 43-51. https://doi.org/10.1108/01437730310457320

Beltran, A. (2019). Female leadership and firm performance. Prague Economic Papers, 28(3), 363-377. https://doi.org/10.18267/j.pep.695

Blau, P. M. (1977). Inequality and heterogeneity, a primitive theory of social structure. Free Press.

Campbell, K., \& Bohdanowicz, L. (2015). Corporate governance and the growing role of women in the boardroom. In M. Aluchna \& G. Aras (Eds.), Transforming governance: new values, new systems in the new business environment (pp. 121-142). Gower.

Campbell, K., \& Mínguez-Vera, A. (2008). Gender diversity in the boardroom and firm financial performance. Journal of Business Ethics, 83(3), 435-451. https://doi.org/10.1007/s10551-007-9630-y

Carter, D. A., Simkinns, B. J., \& Simpson, W. G. (2003). Corporate governance, board diversity, and firm value. The Financial Review, 38(1), 33-53. https://doi.org/10.1111/1540-6288.00034

Černík, D. (2016). Gender board diversity and its impact on firm performance in the Czech Republic (Bachelor thesis). Charles University, Prague, Czech Republic.

Christiansen, L., Lin, H., Pereira, J., Topalova, P., \& Turk, R. (2016). Gender diversity in senior positions and firm performance, evidence from Europe (IMF Working Paper No 16/50). International Monetary Fund. https://doi.org/10.5089/9781513553283.001

Coad, A., Segarra, A., \& Teruel, M. (2013). Like milk or wine. Does firm performance improve with age? Structural Change and Economic Dynamics, 24(1), 173-189. https://doi.org/10.1016/j.strueco.2012.07.002

Cook, A., \& Glass, C. (2014). Women and top leadership positions: Towards an institutional analysis. Gender, Work \& Organization, 21(1), 91-103. https://doi.org/10.1111/gwao.12018

Deloitte. (2017). Missing pieces report: The 2016 board diversity census of women and minorities on fortune 500 boards. http://www2.deloitte.com/us/en/pages/center-for-board-effectiveness/articles/ board-diversity-census-missing-pieces.html

Deloitte. (2017a). Women in the boardroom: A global perspective (5 ${ }^{\text {th }}$ ed). https://www2.deloitte.com/ content/dam/Deloitte/cn/Documents/risk/deloitte-cn-ra-ccg-e1-women-in-the-boardroom-a-global-perspective-fifth-edition.pdf

Desvaux, G., Devillard, S., Labaye, E., Sancier-Sultan, S., Kosseff, C., \& Zelicourt, A. (2017). Women matter: Time to accelerate. Ten years of insights into gender diversity. https://www.mckinsey.com/

Devillard, S., Graven, W., Lawson, E., Paradiso, R., \& Sancier-Sultan, S. (2012). Women matter 2012: Making the breakthrough. https://www.mckinsey.com/ /media/McKinsey/Business\%20Functions/ Organization/Our\%20Insights/Women\%20matter/Women_matter_mar2012_english\%20(1).pdf

Dytrt, Z. (2013). Ženy a management [Women and management]. Bizbooks.

Ellwood, E., \& Garcia-Lacalle, J. (2015). The influence of presence and position of women on the boards of directors: The case of NHS foundation trusts. Journal of Business Ethics, 130, 69-84.

https://doi.org/10.1007/s10551-014-2206-8 
European Commission. (2012). Proposal for a Directive of the European Parliament and of the Council on improving the gender balance among non-executive directors of companies listed on stock exchanges and related measures. https://eur-lex.europa.eu/legal-content/EN/TXT/?uri=celex\%3A52012PC0614

Flabbi, L., Macis, M., Moro, A., \& Schivardi, F. (2019). Do female executives make a difference? The impact of female leadership on gender gaps and firm performance. The Economic Journal, 129(622), 2390-2423. https://doi.org/10.1093/ej/uez012

Gallucci, C., D'Amato, A., \& Santulli, R. (2015). Women on board of directors and firm performance: The moderating role of female ownership. Empirical evidence from the Italian wine industry. Journal of Financial Management Markets and Institutions, 3(2), 225-244.

Green, C. P., \& Homroy, S. (2018). Female directors: Board committees and firm performance. European Economic Review, 102, 19-38. https://doi.org/10.1016/j.euroecorev.2017.12.003

Grosvold, J., \& Brammer, S. J. (2010). National institutional systems as antecedents of female board representation: An empirical study. Corporate Governance: An International Review, 19(2), 116-135. https://doi.org/10.1111/j.1467-8683.2010.00830.x

Guest, P. M. (2009). The impact of board size on firm performance: Evidence from the UK. The European Journal of Finance, 15(4), 385-404. https://doi.org/10.1080/13518470802466121

Hambrick, D. C., \& Mason, P. A. (1984). Upper echelons: The organization as a reflection of its top managers. Academy of Management Review, 9(2), 193-206. https://doi.org/10.5465/amr.1984.4277628

Haslam, S. A., Ryan, M. K., Kulich, C., Trojanowski, G., \& Atkins, C. (2010). Investing with prejudice: The relationship between women's presence on company boards and objective and subjective measures of company performance. British Journal of Management, 21, 484-497. https://doi.org/10.1111/j.1467-8551.2009.00670.x

He, J., \& Huang, Z. (2011). Board informal hierarchy and firm financial performance: Exploring a tacit structure guiding boardroom interactions. Academy of Management Journal, 54(6), 1119-1139. https://doi.org/10.5465/amj.2009.0824

He, X., Inman, J. J., \& Mittal, V. (2007). Gender jeopardy in financial risk taking. Journal of Marketing Research, 44, 414-424. https://doi.org/10.1509/jmkr.45.4.414

Hillman, A. J., Withers, M. C., \& Collins, B. J. (2009). Resource dependence theory: A review. Journal of Management, 35(6), 1404-1427. https://doi.org/10.1177/0149206309343469

Hofstede Insights. (2019). Country comparison. https://www.hofstede-insights.com/country/czechrepublic/

Hult, G. T. M., Ketchen, D. J., Griffith, D. A., Chabowski, B. R., Hamman, M. K., Dykes, B. J., Pollitte, W. A., \& Cavusgil, S. T. (2008). An assessment of the measurement of performance in international business research. Journal of International Business Studies, 39(6), 1064-1080. https://doi.org/10.1057/palgrave.jibs.8400398

Ibhaguia, O. V., \& Olokoyob, F. O. (2018). Leverage and firm performance: New evidence on the role of firm size. North American Journal of Economics and Finance, 45, 57-82. https://doi.org/10.1016/j.najef.2018.02.002

Janošová, L., \& Mikuš, P. A. (2018). Relationship between gender and age diversity among board members and firm performance. In J. Nesleha, F. Hampl, \& M. Svoboda (Eds.), $15^{\text {th }}$ International Scientific Conference on European Financial Systems 2018 (pp. 202-209). Masaryk University.

Joecks, J., Pull, K., \& Vetter, K. (2013). Gender diversity in the boardroom and firm performance: What exactly constitutes a 'critical mass'? Journal of Business Ethics, 118(1), 61-72. https://doi.org/10.2139/ssrn.2009234

Kalsie, A., \& Shrivastav, S. M. (2016). Analysis of board size and firm performance: Evidence from NSE Companies using panel data approach. Indian Journal of Corporate Governance, 9(2), 148-172. https://doi.org/10.1177/0974686216666456

Kanter, R. (1977). Some effects of proportions on group life, skewed sex ratios and responses to token women. American Journal of Sociology, 82(5), 965-990. https://doi.org/10.1086/226425 
Khan, W. A., \& Vieito, J. P. (2013). CEO gender and firm performance. Journal of Economics and Business, 67, 55-66. https://doi.org/10.1016/j.jeconbus.2013.01.003

Konečný, L., \& Částek, O. (2016). The effect of ownership structure on corporate financial performance in the Czech Republic. Ekonomický Časopis, 64(5), 477-498.

Křižková, A. (2003). Kariérní vzorce žen v managementu. Strategie žen v rámci genderového režimu v organizaci. Sociologický časopis, 39(4), 447-469. https://doi.org/10.13060/00380288.2003.39.4.02

Kuncová, M., Hedija, V., \& Fiala, R. (2016). Firm size as a determinant of firm performance: The case of swine raising. Agris on-line Papers in Economics and Informatics, 8(3), 77-89. https://doi.org/10.7160/aol.2016.080308

Lee, C., \& Farh, J. (2004). Joint effects of group efficacy and gender diversity on group cohesion and performance. Applied Psychology, 53(1), 136-154. https://doi.org/10.1111/j.1464-0597.2004.00164.x

Lückerath-Rovers, M. (2013). Women on boards and firm performance. Journal of Management \& Governance, 17(2), 491-509. https://doi.org/10.1007/s10997-011-9186-1

Machek, O. (2013). Long-term predictive ability of bankruptcy models in the Czech Republic: Evidence from 2007-2012. Central European Business Review, 3(2), 14-17. https://doi.org/10.18267/j.cebr.80

Majumdar, S. K. (1997). The impact of size and age on firm-level performance: Some evidence from India. Review of Industrial Organization, 12(2), 231-241. https://doi.org/10.1023/A:1007766324749

Melsom, A. M. (2015). The gender of managers and sickness absence. Sagen Open, 5(1), 1-12. https://doi.org/10.1177/2158244015574208

Miller, T., \& del Carmen Triana, M. (2009). Demographic diversity in the boardroom: Mediators of the board diversity-firm performance relationship. Journal of Management Studies, 46(5), 755-786. https://doi.org/10.1111/j.1467-6486.2009.00839.x

Neumaierová, I., \& Neumaier, I. (2005). Index IN05. In P. Červinek (Ed.), Sborník př́spěvků z mezinárodní vědecké konference Evropské finanční systémy (pp. 143-148). Masaryk University.

Pasaribu, P. (2017). Female directors and firm performance: Evidence from UK listed firms. Gadjah Mada International Journal of Business, 19(2), 146-166. https://doi.org/10.22146/gamaijb.15619

Pfeffer, J. (1972). Size and composition of corporate boards of directors: The organization and its environment. Administrative Science Quarterly, 17(2), 218-228. https://doi.org/10.2307/2393956

Phillips, P. A., \& Sipahioglu, M. A. (2004). Performance implications of capital structure; evidence from quoted U. K. organisations with hotel interests. The Services Industry Journal, 24(5), 1-21. https://doi.org/10.1080/0264206042000276829

Public Opinion Research Center. (2016). Public opinion on the role of men and women in family - February 2016. https://cvvm.soc.cas.cz/en/press-releases/other/relations-attitudes/4106-public-opinionon-the-role-of-men-and-women-in-family-february-2016

Radu, C., Deaconu, A., \& Frasineanu, C. (2017). Leadership and gender differences-are men and women leading in the same way? In A. Alvinius (Ed.), Contemporary leadership challenges (pp. 63-81). IntechOpen. https://doi.org/10.5772/65774

Rose, C. (2007). Does female board representation influence firm performance? The Danish evidence. Corporate Governance, 15(2), 404-413. https://doi.org/10.1111/j.1467-8683.2007.00570.x

Shrader, C. B., Blackburn, V., \& Iles, P. (1997). Women in management and firm financial performance: An exploratory study. Journal of Managerial Issues, 9(3), 355-372.

Torchia, M., Calabro, A., \& Huse, M. (2011). Women directors on corporate boards: From tokenism to critical mass. Journal of Business Ethics, 102, 299-317. https://doi.org/10.1007/s10551-011-0815-Z

Virtanen, A. (2012). Women on the boards of listed companies: Evidence from Finland. Journal of Management \& Governance, 16(4), 571-593. https://doi.org/10.1007/s10997-010-9164-z

Wang, Y.-H. (2020). Does board gender diversity bring better financial and governance performances? An empirical investigation of cases in Taiwan. Sustainability, 12(8), 3205.

https://doi.org/10.3390/su12083205 